\title{
Amberlyst-15 in organic synthesis
}

\author{
Rammohan Pal, Taradas Sarkar and Shampa Khasnobis \\ Department of Chemistry, Acharya Jagadish Chandra Bose College, \\ 1/1B, A. J. C. Bose Road, Kolkata 700 020, India \\ E-mail:pal_rammohan@yahoo.com
}

\begin{abstract}
Commercially available Amberlyst-15 has played an important role in organic synthesis. This review summarizes the versatile synthetic applications of Amberlyst-15 in different chemical transformations. Reactions include esterification, transesterification, Michael addition, azaMichael addition, Prins cyclization, Friedel-Crafts alkylation, acylation, metal free hydroarylation, hydroalkylation, halogenation, protection of carbonyls, amines, deprotection of acetals, acetates, Boc-protected amines, cleavage of epoxides, crossed-aldol condensation, synthesis of quinolines, pyrazolines, indolinones, acridines, calix[4]pyrroles, xanthenes, coumarins, benzopyrans theaspirane, furans, and substituted phosphonates. Applications of this catalyst allow mild and highly selective transformations and synthesis in a facile and environmentally friendly manner. The catalysts can be regenerated and recycled.
\end{abstract}

Keywords: Amberlyst-15, heterogeneous, recyclable, acid catalysis, organic synthesis

\section{Contents}

1. Introduction

2. General Information and Structural Features of Amberlyst-15

3. Esterification and Transesterification Reaction

4. Michael Addition Reaction

5. Aza-Michael Addition Reaction

6. $\mathrm{S}_{\mathrm{N}} 2$ ' Reaction

7. Prins Reaction

8. Friedel-Crafts Reaction

8.1 Alkylation

8.2 Acylation

9. Hydroarylation and Hydroalkylation Reaction

10. Halogenation Reaction 
11. Protection and Deprotection Reactions

11.1 Protection of carbonyls and amines

11.1.1 Acetalization reaction

11.1.2 Thioacetalization reaction

11.1.3 Acyloxy-acylation reaction

11.1.4 N-tert-butoxycarbonylation reaction

11.2 Deprotection of acetals, thioacetals, acetates and Boc-protected amines

11.2.1 Deacetalization reaction

11.2.2 Dethioacetalization reaction

11.2.3 Hydrolysis of aromatic acetates

11.2.4 Deprotection of Boc-protected amines

12. Epoxide Ring Opening Reaction

13. Condensation Reaction

13.1 Crossed-aldol condensation reaction

13.2 Condensation of carbonyl compounds and indoles

14. Multicomponent Reaction

15. Formation of Nitrogen Heterocycles

15.1 Synthesis of quinolines

15.2 Synthesis of pyrazolines

15.3 Synthesis of indolin-3-ones

15.4 Synthesis of 1,8-dioxodecahydroacridines

15.5 Synthesis of calix[4]pyrroles

16. Formation of Oxygen Heterocycles

16.1 Synthesis of xanthenes

16.2 Synthesis of coumarins

16.3 Synthesis of benzopyrans

16.4 Synthesis of theaspiranes

16.5 Synthsis of furan derivatives

17. Formation of Homocyclic Compounds

18. Synthesis of Substituted Phosphonates

18.1 Synthesis of $\alpha$-hydroxy phosphonates

18.2 Synthesis of sulphonamido-phosphonates

18.3 Synthesis of alkyl/aryl/allyl/heteroaryl phosphonates

19. Synthesis of $\beta$-Enaminones and $\beta$-Enaminoesters

20. Conclusion

Acknowledgement

References 


\section{Introduction}

In the past decade, the chemistry of Amberlyst-15 has experienced a rapid development. This growing interest in Amberlyst-15 is mainly due to its mild and highly selective properties, combined with its environmentally benign character and commercial availability. Amberlyst-15 is now routinely used in organic synthesis as other heterogeneous reusable acid catalysts ${ }^{1 \mathrm{a}-\mathrm{d}}$ for various selective transformations of simple and complex molecules. The purpose of the present review is to summarize the utility of Amberlyst- $15^{1 \mathrm{e}-\mathrm{i}}$ with emphasis on recent synthetic applications; literature coverage is through the end of 2011.

\section{General Information and Structural Features of Amberlyst-15}

Amberlyst-15 is brown-grey solid having the following physical properties ${ }^{2 a}$

Ionic form as shipped : hydrogen

Concentration of active sites: $\geq 1.7 \mathrm{eq} / \mathrm{L} ; \geq 4.7 \mathrm{eq} / \mathrm{kg}$

Moisture holding capacity : 52 to $57 \%$ ( $\mathrm{H}^{+}$form)

Shipping weight $\quad: 770 \mathrm{~g} / \mathrm{L}$

Particle size : 0.600 to $0.850 \mathrm{~mm}$

Average pore diameter $\quad: 300 \AA$

Total pore volume $\quad: 0.40 \mathrm{~mL} / \mathrm{g}$

Maximum operating temperature: $120^{\circ} \mathrm{C}\left(250^{\circ} \mathrm{F}\right)$

Figure 1 (left) shows an SEM of Amberlyst-15 resin. ${ }^{2 \mathrm{~b}}$ It is a macro reticular polystyrene based ion exchange resin with strongly acidic sulfonic group (Figure 1, right). Thus, it serves as an excellent source of strong acid. It has been used in various acid catalyzed reactions. It is easy to measure, safe to use, and readily removed at the end of the reaction. An additional advantage is that the catalyst can be regenerated and can be used several times.
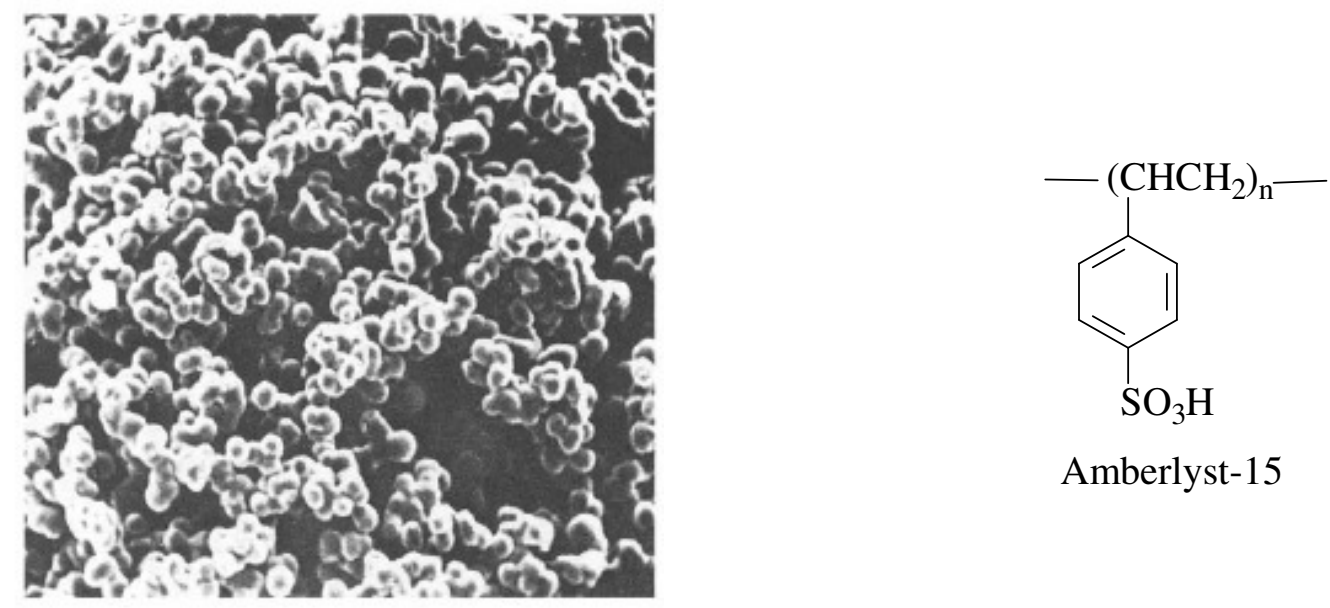

Amberlyst-15

\section{Figure 1}




\section{Esterification and Transesterification Reaction}

Amberlyst-15 is a powerful and selective acid catalyst for esterification reactions. Petrini et al. have reported a mild and selective methyl esterification of aliphatic carboxylic acids using Amberlyst-15 in methanol at room temperature in excellent yield (Scheme 1). ${ }^{\text {a }}$ No racemisation, epimerization and ketalization products have been observed with this method. Excellent results are obtained in the esterification of bile acids. However, aromatic carboxylic acid such as 5methylfuroic acid and conjugated carboxylic acid such as trans-aconitic acid do not react with methanol at room temperature. They can be transformed into esters only by refluxing the mixture for a long time.

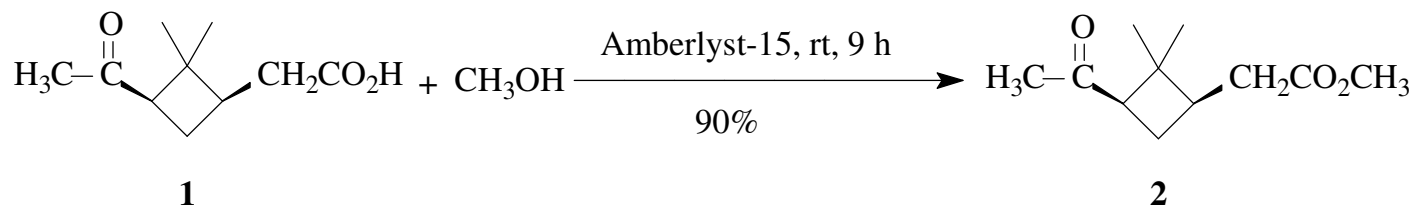

\section{Scheme 1}

Amberlyst-15 has also been used for production of biodiesel (BD). Talukder and coauthors reported that palm fatty acid distillate (PFAD), a byproduct from the palm oil refinery process, has been utilized as an alternative feedstock for biodiesel production via Amberlyst-15 catalyzed esterification. $^{3 \mathrm{~b}}$ The BD yield obtained using Amberlyst-15 is $97 \%$.

Transesterification of esters with alcohols has been accomplished using Amberlyst-15. Chavan and co-workers reported that Amberlyst-15 acts as a Bronsted acid catalyst for transesterification of various $\beta$-ketoesters with different alcohols including allylic alcohols and sterically hindered secondary and primary alcohols in refluxing conditions. In a specific example, the transesterified $\beta$-ketoester 4 can be prepared from $\beta$-ketoesters 3 using Amberlyst15 under refluxing in toluene. (Scheme 2). ${ }^{3 \mathrm{c}}$

Pappu et $a l .^{3 \mathrm{~d}}$ reported that methyl stearate, a model biodiesel compound undergoes transesterification with higher alcohol n-butanol using Amberlyst-15 as acid catalyst.

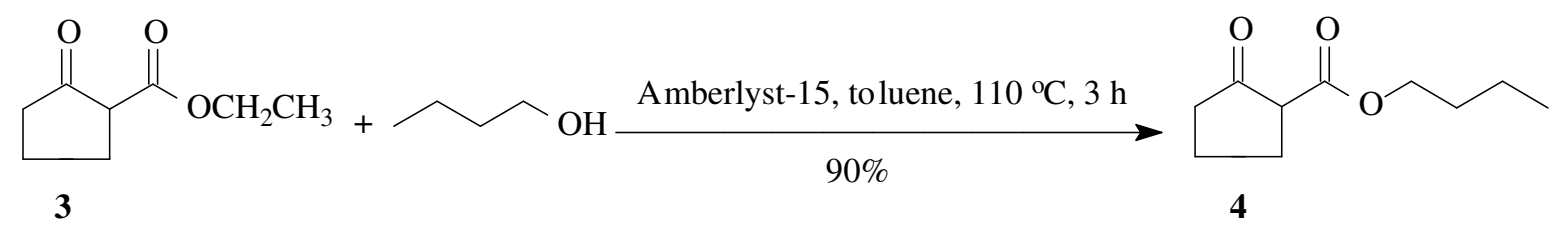

\section{Scheme 2}




\section{Michael Addition Reaction}

Michael addition of pyrroles to $\alpha, \beta$-unsaturated ketones has been accomplished in presence of Amberlyst-15 in acetonitrile at room temperature to obtain the corresponding 2-alkyl and 2,5dialkyl pyrroles in good to excellent yields (65-91\%) without polymerization. The method can thus be used to produce C-alkylated pyrroles 6 and 7 from pyrroles and 5 (Scheme 3). ${ }^{4 a}$ Acetonitrile was found to be the best solvent in this reaction.

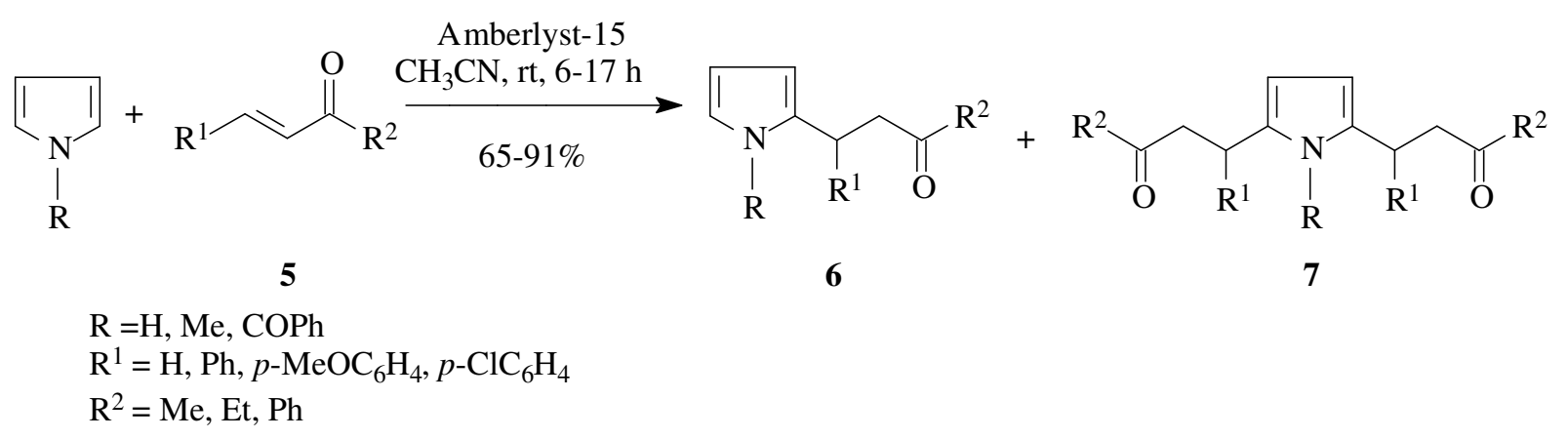

\section{Scheme 3}

Bandini et al. reported Amberlyst-15 catalyzed Michael-type addition of indoles to $\alpha, \beta$ unsaturated carbonyl and nitro compounds. Thus, when 2-methylindole was treated with $\mathbf{8}$ in presence of Amberlyst-15 Michael addition adduct 9 was formed in $94 \%$ yield (Scheme 4). ${ }^{4 \mathrm{~b}}$

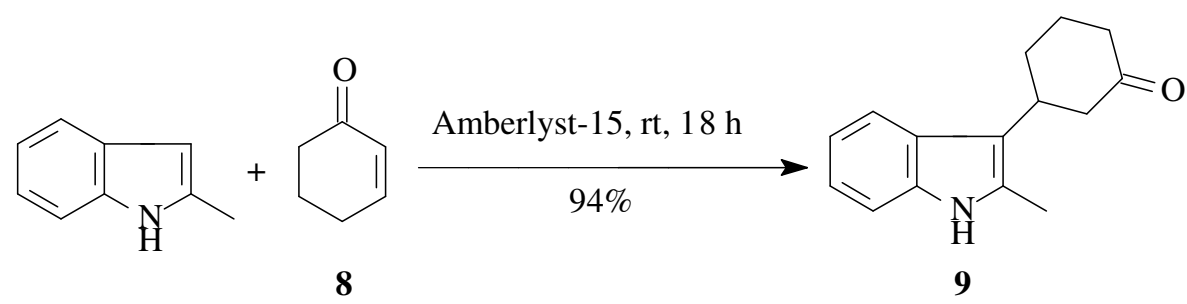

\section{Scheme 4}

\section{Aza-Michael Addition Reaction}

Aza-Michael reaction of a series of amines with $\alpha, \beta$-unsaturated carbonyls and nitriles to produce $\beta$-amino carbonyls and nitrile compounds $\mathbf{1 2}$ in good to excellent yields, using Amberlyst-15 under solvent-free conditions was reported by Das and Chowdhury (Scheme 5). ${ }^{5 a}$ 
Esteves et al., however, used primary and secondary aliphatic amines as substrates with methyl vinyl sulfone 13a and vinyl $p$-aminophenylsulfone 13b in presence of Amberlyst-15 $(30 \%, \mathrm{w} / \mathrm{w})$ at room temperature to produce the corresponding aza-Michael addition product 14 in moderate to high yield (Scheme 6). ${ }^{5 b}$

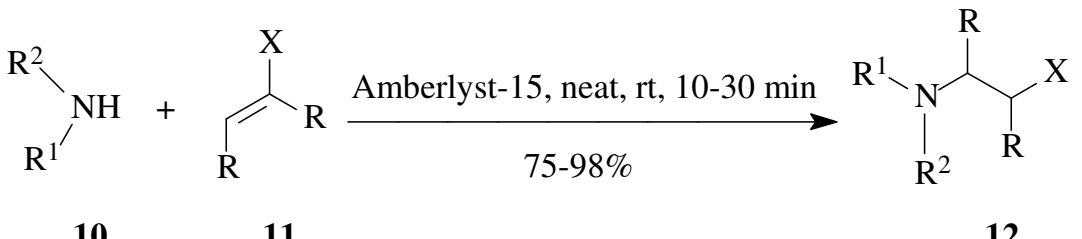

$$
\mathrm{X}=\mathrm{COMe}, \mathrm{COOMe}, \mathrm{CN}
$$

\section{Scheme 5}

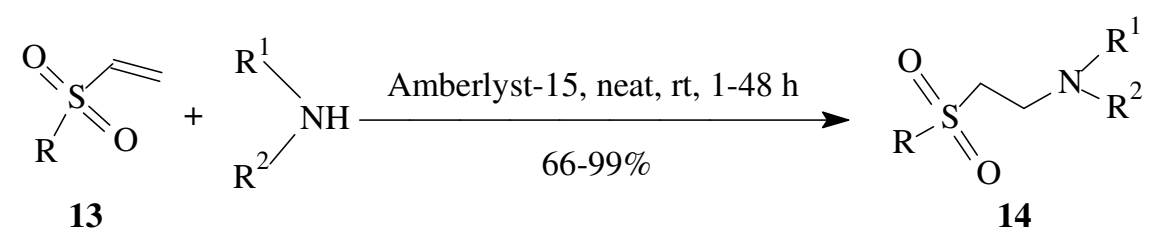

a: $\mathrm{R}=\mathrm{Me} ; \mathbf{b}: \mathrm{R}=p-\mathrm{H}_{2} \mathrm{NC}_{6} \mathrm{H}_{4}$

\section{Scheme 6}

\section{6. $\mathrm{S}_{\mathrm{N}} 2^{\prime}$ Reaction}

Nucleophilic substitution reaction in allylic alcohols was also studied using Amberlyst-15 as catalyst. The Baylis-Hillman adduct 15 which contains allylic alcohol functionality are highly useful in various chemical transformation and in synthesis of several bioactive compounds. ${ }^{\text {a-d }}$ 


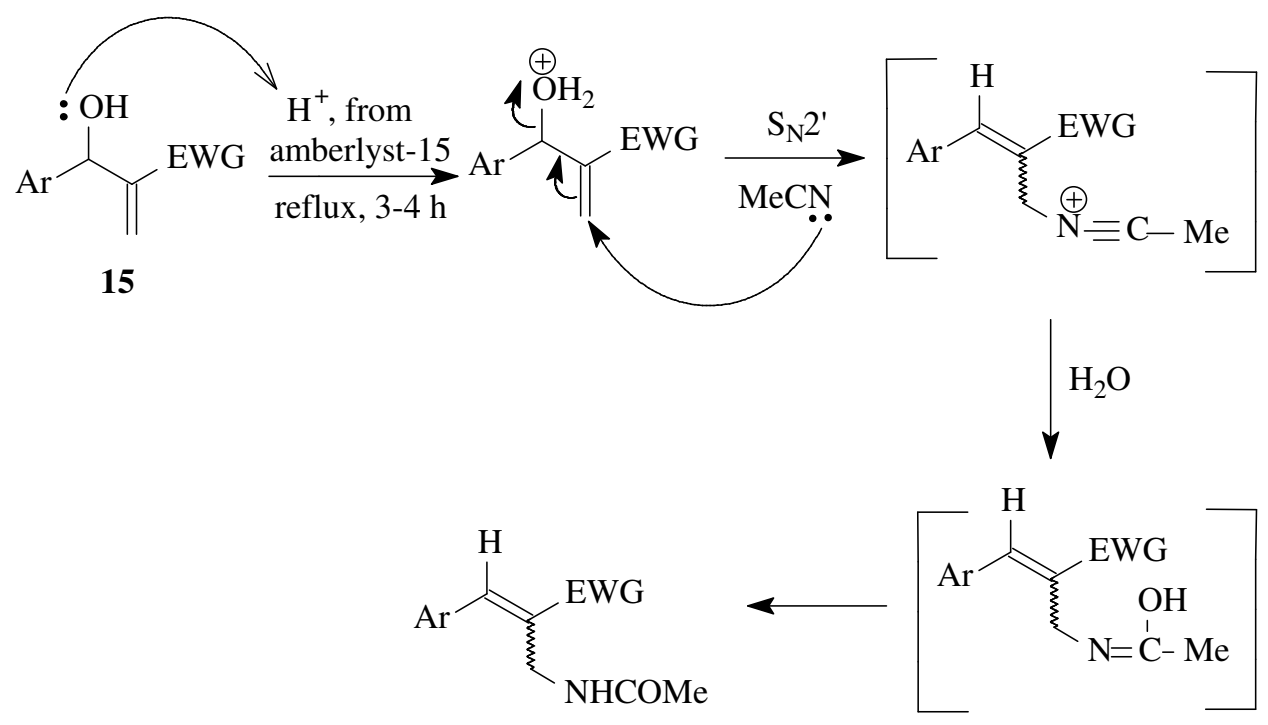

16

\section{Scheme 7}

Das and co-workers utilized these adducts for the stereoselective synthesis of a series of $(E)$ and (Z) allyl amides 16 through $\mathrm{S}_{\mathrm{N}} 2$ ' reaction of $\mathbf{1 5}$ and MeCN, using Amberlyst-15 as acid catalyst (Scheme 7). ${ }^{\text {a }}$

$(E)$-cinnamyl alcohols $\mathbf{1 8}^{7 \mathrm{~b}}$ were also synthesized from the isomerization of Baylis-Hillman adduct 15 using Amberlyst-15 as a heterogeneous reusable catalyst (Scheme 8). The plausible mechanism for the formation of allyl primary acetates 17, from $\mathbf{1 5}$ is similar to that in Scheme 7. Compound 17 on hydrolysis with $\mathrm{K}_{2} \mathrm{CO}_{3}$ in $\mathrm{MeOH}$ afforded the corresponding cinnamyl alcohols 18.<smiles>CC(=[W])C(O)[AlH2]</smiles>

15

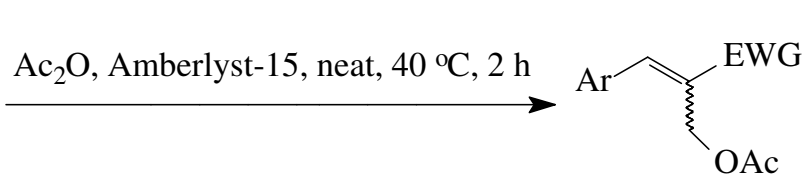

17

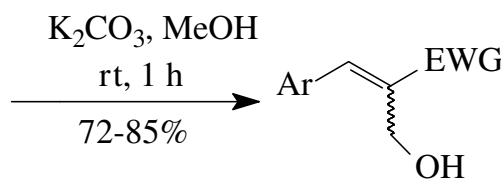

18

\section{Scheme 8}




\section{Prins Reaction}

The acid catalyzed condensation of olefins with carbonyl compounds known as Prins reaction is an important carbon-carbon bond forming reaction. ${ }^{8 \mathrm{a}, \mathrm{b}}$ The tetrahydropyran ring is a part of the backbone of various important carbohydrates and natural products. ${ }^{9 a, b}$

Yadav et al. reported that Amberlyst-15 catalyses the synthesis of tetrahydropyranols through the Prins-type cyclization. Thus, when 1-phenyl-3-buten-1-ol 19 and benzaldehyde was stirred in refluxing 1,2-dichloroethane in presence of Amberlyst-15 for 2 hrs. 2,6-Diphenyl-4hydroxytetrahydropyran $\mathbf{2 1}$ was produced in $88 \%$ yield with high diastereoselectivity. The formation of $\mathbf{2 1}$ may be explained by Prins-type cyclization of the intermediate hemi-acetal 20 (Scheme 9). ${ }^{10}$

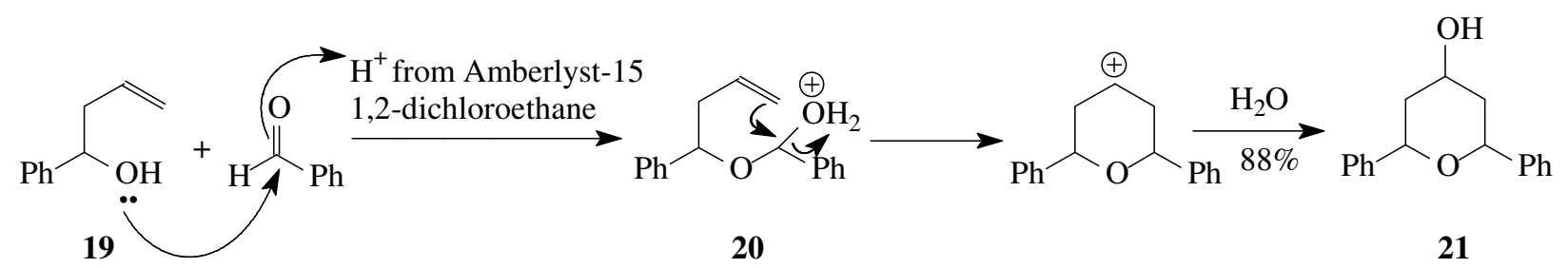

\section{Scheme 9}

\section{Friedel-Crafts Reaction}

Friedel-Crafts reaction of aromatic and heteroaromatic compounds is one of the fundamental reactions for forming carbon-carbon bond. Friedel-Crafts alkylation and acylation reactions have been studied by using Amberlyst-15 as acid catalyst.

\subsection{Alkylation}

Kadam et al. demonstrated that Amberlyst-15 can act as a powerful catalyst for the alkylation of activated arenes or heteroarenes and $\alpha$-amido sulfones. Friedel-Crafts alkylation by various $\alpha$ amido sulfones 22 was achieved on treatment with 1,2,4-trimethoxybenzene using Amberlyst-15 in refluxing $\mathrm{CH}_{2} \mathrm{Cl}_{2}$ to give the products 23 in very good yield (Scheme 10). ${ }^{1 \text { a }}$ The reaction of $N$-benzyloxycarbonylaminophenyl-p-tolylsulfones with indoles (heteroarenes) afforded C-3 alkylation of indoles in moderate yield. 


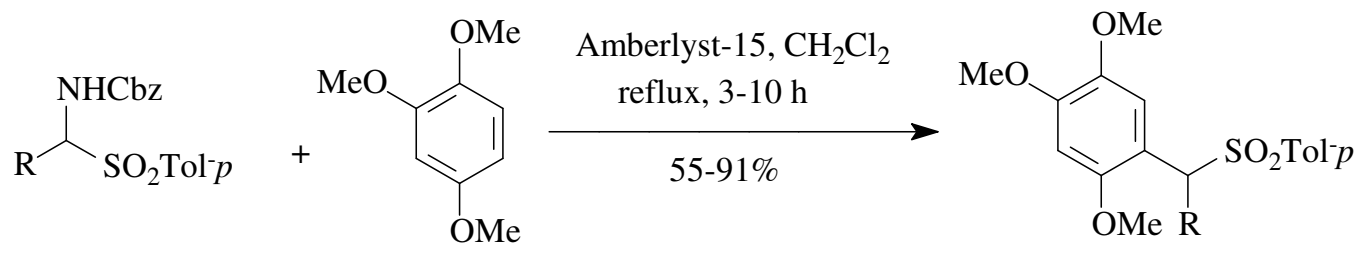

22

23

$\mathrm{R}=$ alkyl, aryl

\section{Scheme 10}

Alkylated phenols are widely used as additives in gasolines, lubricants, and a host of consumer products. ${ }^{11 \mathrm{~b}}$ Various alkylated phenols $\mathbf{2 4}$ was synthesized by Ma and co-workers from phenol and olefins using eco-friendly heterogeneous catalyst Amberlyst-15 (Scheme 11). ${ }^{11 \mathrm{c}}$ The mechanism involves an exothermic reaction between olefin and benzene sulphonic acid (from Amberlyst-15) to form an ester followed by three reaction pathways leading to direct Oalkylation, o-C-alkylation and $p$-C-alkylation.

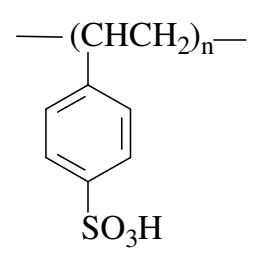

Amberlyst-15

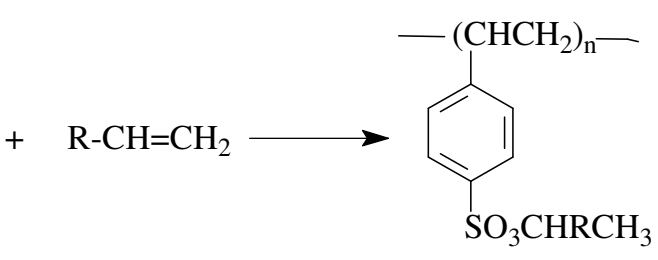

Ester

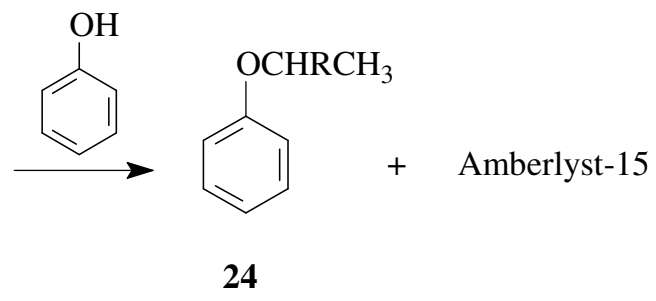

$O$-alkylation

\section{Scheme 11}

Regioselective alkylation at the C-1 position of 2-naphthol using Amberlyst-15 was reported by Das et al. When a mixture of $\beta$-naphthol, benzylic/allylic alcohol and Amberlyst-15 was refluxed in 1,2-dichloroethane (DCE), the corresponding alkylation products 25 and $\mathbf{2 6}$ was produced respectively (Scheme 12). ${ }^{11 \mathrm{~d}}$ Compounds 25 and 26 shows interesting biological properties, including antitubercular activity ${ }^{12 a, b}$ and inhibitory effect on cyclooxygenease I and II. $^{12 \mathrm{c}}$ Also several naphthol compounds that are formed are also useful intermediates in organic synthesis. $^{12 \mathrm{~d}, \mathrm{e}}$ 


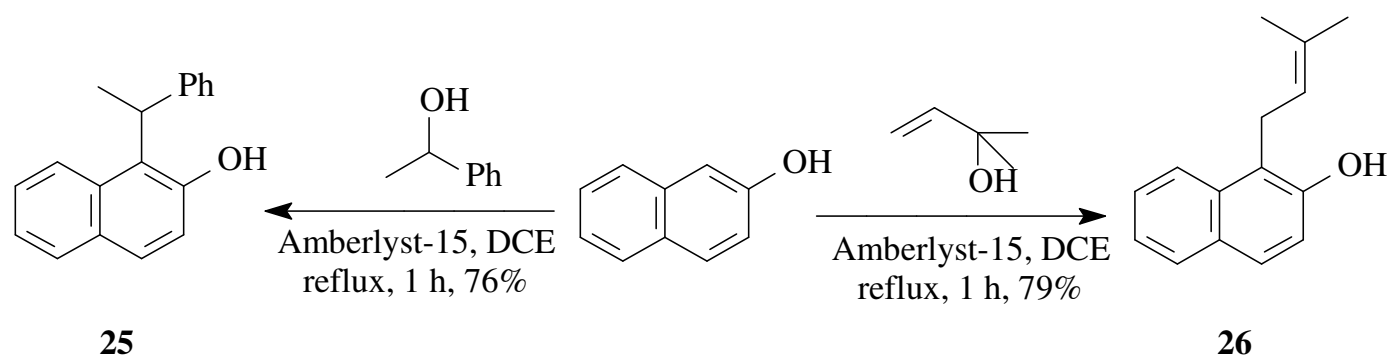

Scheme 12

\subsection{Acylation}

Heteroaromatics like, indole, 2-methylindole and pyrrole undergoes Friedel-Crafts acylation reactions in presence of Amberlyst-15. Thus indole, 2-methylindole and pyrrole were treated with $\mathrm{Ac}_{2} \mathrm{O}$ under solvent-free conditions at room temperature for $3 \mathrm{hrs}$ in presence of Amberlyst15 afforded the acetylation products of the compounds (Scheme 13). ${ }^{13 a}$ Indole produced 3acetylindole and $N$-acetylindole. On the other hand, 2-methylindole produced the $N$-acetyl-2methylindole 27a, N,3-diacetyl-2-methylindole $\mathbf{2 7 b}$ and 5-acetyl-2-methylindole 27c on treatment with $\mathrm{Ac}_{2} \mathrm{O}$ in presence of Amberlyst-15. Pyrrole yielded 3-acetylpyrrole and 2,4diacetylpyrrole under the same conditions.
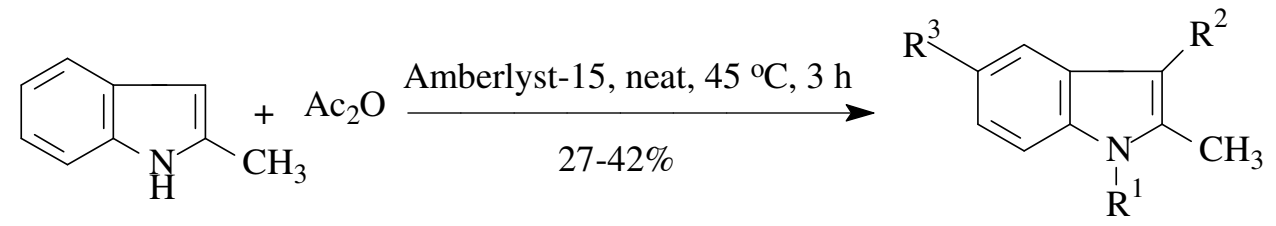

27

a: $\mathrm{R}^{1}=\mathrm{Ac} ; \mathrm{R}^{2}=\mathrm{R}^{3}=\mathrm{H}$

b: $\mathrm{R}^{1}=\mathrm{R}^{2}=\mathrm{Ac} ; \mathrm{R}^{3}=\mathrm{H}$

c: $\mathrm{R}^{1}=\mathrm{R}^{2}=\mathrm{H} ; \mathrm{R}^{3}=\mathrm{Ac}$

\section{Scheme 13}

A series of $N$-sulfonamides $\mathbf{2 9}$ were synthesized from sulfonamides $\mathbf{2 8}$ and acid anhydrides by Friedel-Crafts acylation reaction using Amberlyst-15 under solvent-free conditions at room temperature (Scheme 14). ${ }^{13 \mathrm{~b}} \mathrm{Wu}$ et al. reported that Amberlyst-15 is the best catalyst amongst the previously reported catalyst for the same reaction. 


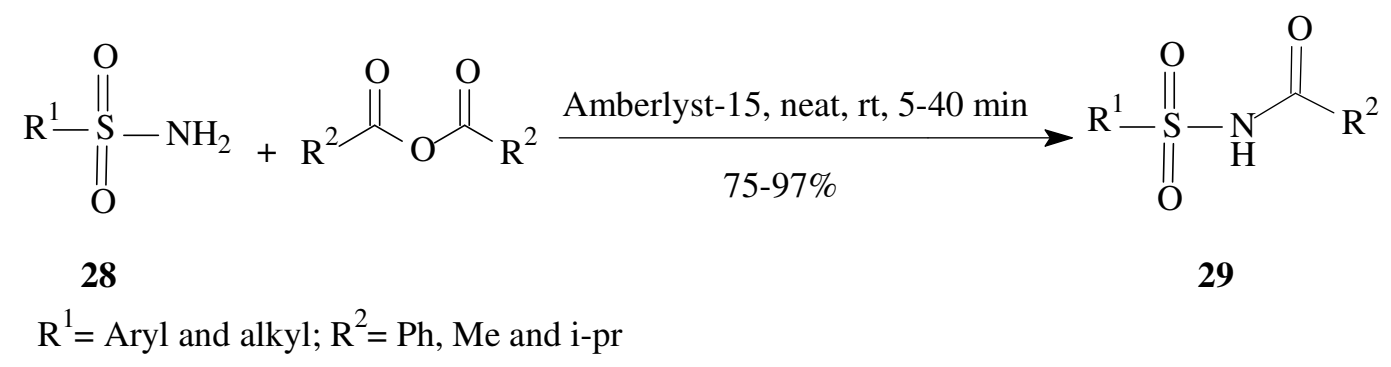

\section{Scheme 14}

\section{Hydroarylation and Hydroalkylation Reaction}

Hydroarylation and hydroalkylation of styrenes was achieved by Das et al. using Amberlyst-15 (Scheme 15). ${ }^{14}$ Various styrenes $\mathbf{3 0}$ when treated with different aromatic compounds or 1,3dicarbonyl compounds underwent hydroarylation or hydroalkylation reactions to produce the diarylalkanes $\mathbf{3 1}$ and alkylation products $\mathbf{3 2}$ respectively. Both the reactions were conducted in 1,2-dichloroethane (DCE) at $80^{\circ} \mathrm{C}$.

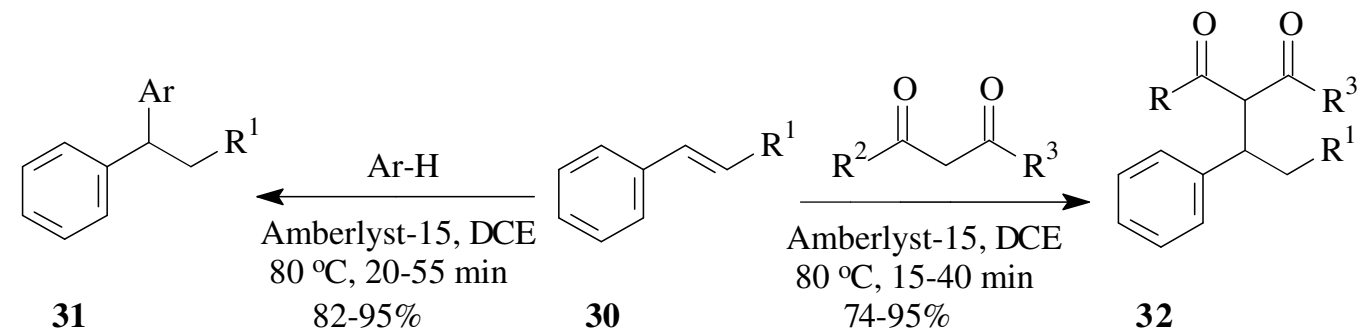

\section{Scheme 15}

\section{Halogenation Reaction}

$\mathrm{N}$-Halosuccinimides are powerful and selective halogenating reagents for organic substrates. Various 1,3-keto-esters can be selectively halogenated at the 2-position with $N$-halosuccinimides using Amberlyst-15 as a heterogeneous solid catalyst. The 2-halogenated products $\mathbf{3 4}$ can be prepared from $\beta$-ketoesters 33 in good yields under mild conditions (Scheme 16). ${ }^{15 a}$ Cyclic ketones can also be directly halogenated at the $\alpha$-position by NXS under the same reaction conditions. 


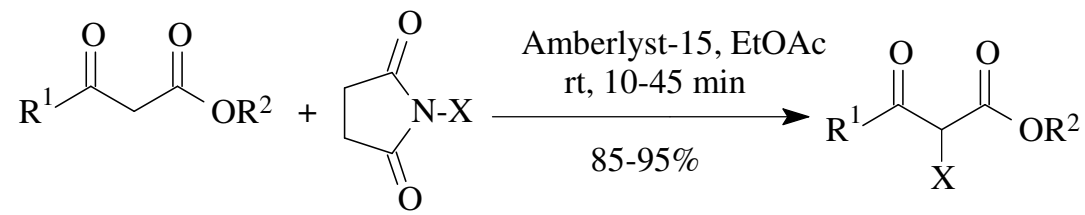

33

$$
\mathrm{X}=\mathrm{Br}, \mathrm{Cl}, \mathrm{I}
$$

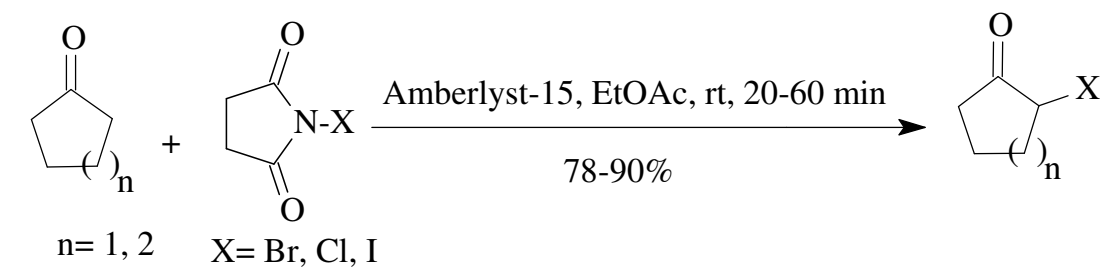

\section{Scheme 16}

Amberlyst-15 can also be used for the iodination of primary, secondary allylic and benzylic alcohols using NaI. $p$-Methoxybenzylalcohol $\mathbf{3 5}$ is selectively iodinated with NaI/Ambeylyst-15 in acetonitrile at room temperature to give $\mathbf{3 6}$ in good yield (Scheme 17) ${ }^{15 \mathrm{~b}}$ Electron donating groups attached to the benzene ring accelerate the iodination reaction and electron-withdrawing group retard the transformation.

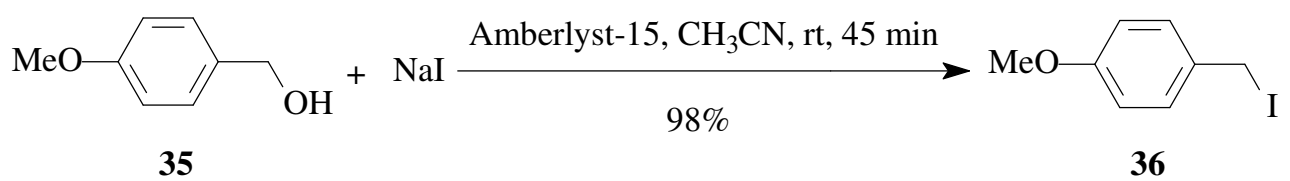

\section{Scheme 17}

\section{Protection and Deprotection Reactions}

Protection and deprotection reactions are very important and widely used strategy for organic synthesis. Reactions involving selective protection of functional groups such as carbonyl, hydroxyl carboxylic acids and amines in presence of other functional groups, and their deprotection, are of common importance in the multi-step synthesis of complex natural products $^{16 \mathrm{a}, \mathrm{b}}$. 


\subsection{Protection of carbonyls and amines}

Protection of carbonyl group as acetals (acetalization reaction), thioacetals (thioacetalization reaction) and diacetates (acylation reaction) are widely used owing to their stability towards a wide range of reagents. ${ }^{17 a, b}$ A number of methods have been reported for acetalization, ${ }^{18 a, b}$ thioacetalization, ${ }^{19 \mathrm{a}, \mathrm{b}}$ and acylation ${ }^{20 \mathrm{a}-\mathrm{c}}$ reactions. Protection of amines as $N$-tert-butoxycarbonyl $\left(N\right.$-Boc) group has become very popular in peptide synthesis. ${ }^{21 a, b}$ A survey of the literature revealed that Amberlyst-15 has been efficiently used for the protection of carbonyl and amine functional groups.

\subsubsection{Acetalization reaction}

Patwardhan and Dev reported that carbonyl group can be protected by acetalization process using catalytic amount of Amberlyst-15. Thus, when benzaldehyde was treated with triethyl orthoformate in presence of Amberlyst-15, the corresponding acetal 37 was obtained in excellent yield (Scheme 18). ${ }^{22 a}$ In case of ketones the reaction produced the corresponding ketals and in some cases the enol ethers was directly formed in good yield under similar conditions.

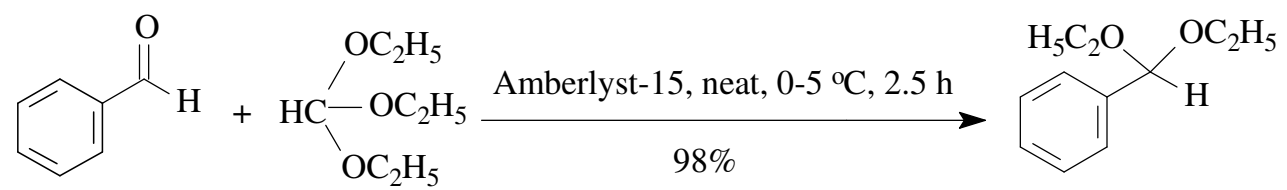

37

\section{Scheme 18}

\subsubsection{Thioacetalization reaction}

Chemoselective thioacetalization of carbonyl group with Amberlyst-15 was reported by Perni et al. when benzaldehyde and acetophenone was allowed to react with one equivalent of ethanedithiol and Amberlyst-15 in chloroform overnight at room temperature, a high yield of 38 was obtained and the ketone recovered in unchanged condition (Scheme 19). ${ }^{2 \mathrm{~b}}$ However, ketones can be protected by this method by refluxing the reaction mixture. 


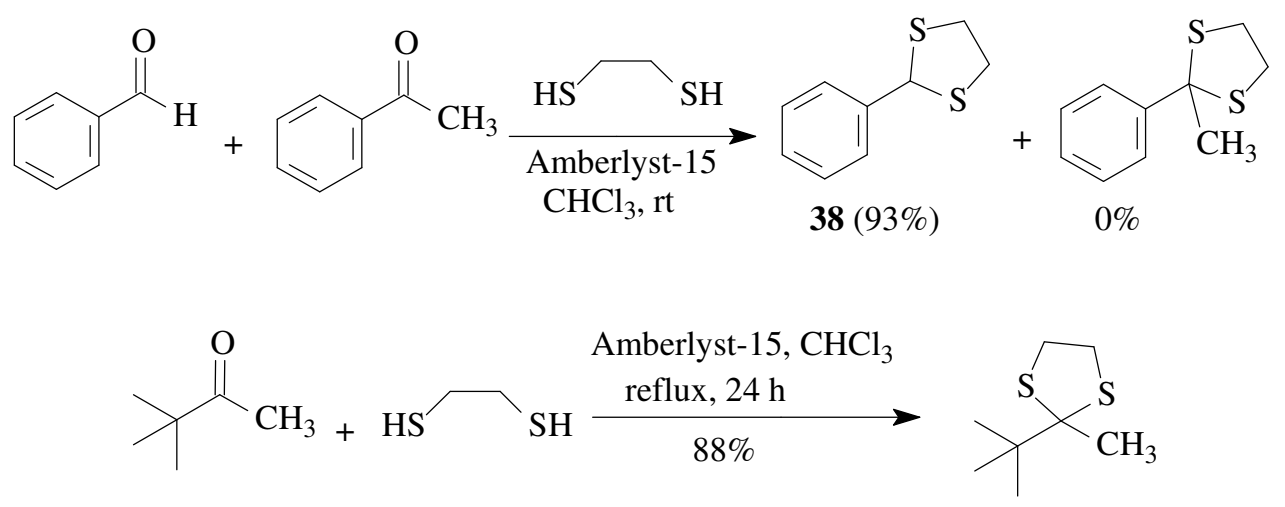

Scheme 19

\subsubsection{Acyloxy-acylation reaction}

Reddy et al. demonstrated that Amberlyst-15 works as an efficient catalyst for chemoselective acyloxy-acylation of aldehydes. Thus, when a mixture of benzaldehyde and acetophenone in (1:1) ratio was reacted with acetic anhydride in presence of Amberlyst-15 catalyst in dichloromethane at room temperature, the 1,1-diacetate of benzaldehyde was exclusively formed (Scheme 20). ${ }^{22 \mathrm{c}}$

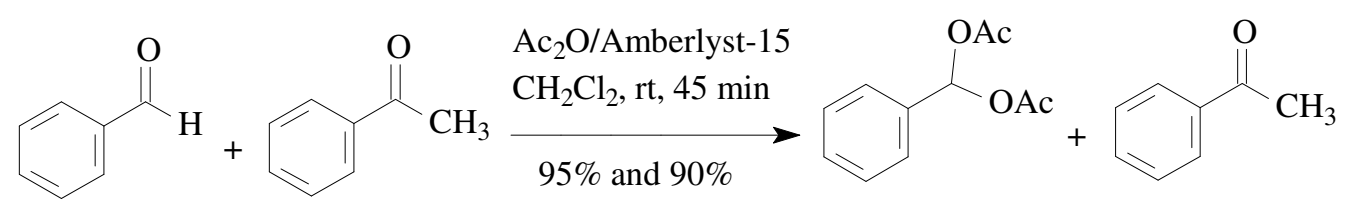

\section{Scheme 20}

\subsection{4 $N$-tert-butoxycarbonylation reaction}

Chemoselective $N$-tert-butoxycarbonylation of amines in presence of Amberlyst-15 was reported by Kumar et al. A variety of primary, secondary and aryl amines were reacted with di-tert-butyl dicarbonate (Boc) $)_{2} \mathrm{O}$ in presence of Amberlyst-15 in $\mathrm{CH}_{2} \mathrm{Cl}_{2}$ at room temperature to produce the corresponding $N$-tert-butylcarbamates in good to excellent yields. However, 2-aminophenol 39 and proline 41 reacted slowly with (Boc) $)_{2} \mathrm{O}$ in comparison with the other amines, to yield $\mathbf{4 0}$ and 42 respectively (Scheme 21). ${ }^{22 \mathrm{~d}}$ This method was found to be selective for the protection of amines as the hydroxyl and carboxylic acid groups were not affected during the reaction. 


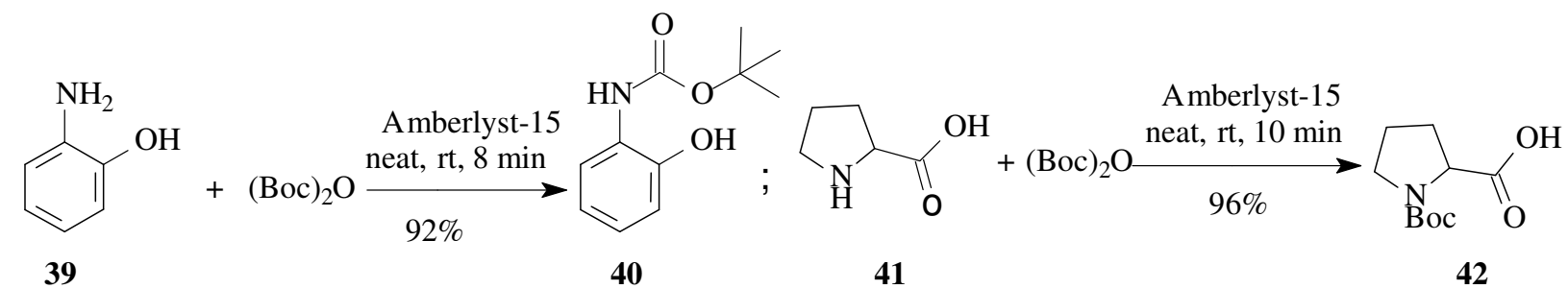

Scheme 21

\subsection{Deprotection of acetals, thioacetals, acetates and Boc-protected amines}

The importance of the deprotection of acetals, ${ }^{23 a-c}$ thioacetals, ${ }^{24 a-c}$ acetates $^{25 a-c}$ and Boc-protected amines $^{26 a, b}$ to their corresponding functional groups in multi-step organic synthesis can not be overstated. Amberlyst-15 has been shown to catalyze such reactions efficiently to give good yields of the deprotected products.

\subsubsection{Deacetalization reaction}

Coppola demonstrated that Amberlyst-15 can be used as an excellent catalyst for the hydrolysis of acetals or ketone acetals to the corresponding carbonyl derivatives (Scheme 22). ${ }^{27 a}$ Thus, when a solution of acetal $\mathbf{4 3}$ in acetone, containing water is added to Amberlyst-15 and the mixture is stirred at room temperature for $10 \mathrm{~min}$ the corresponding carbonyl compounds $\mathbf{4 4}$ was produced in high yield.

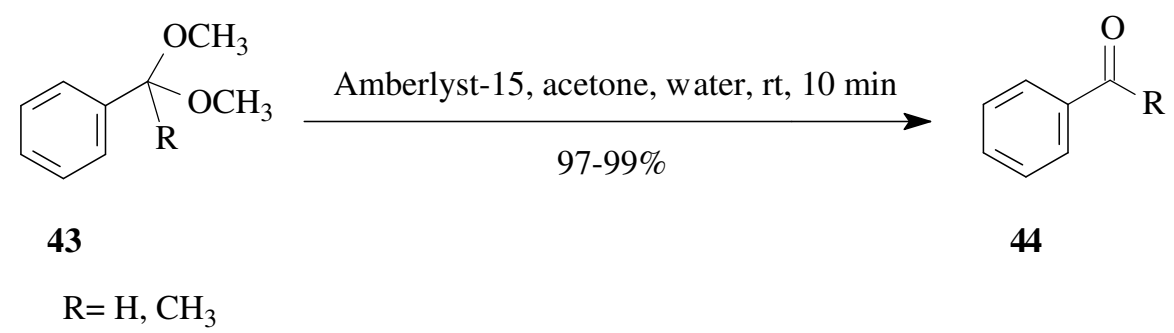

\section{Scheme 22}




\subsubsection{Dethioacetalization reaction}

Ballini and Petrini reported a new procedure for dethioacetalization via equilibrium exchange with aqueous acetone, paraformaldehyde and Amberlyst-15 as acidic catalyst at $80{ }^{\circ} \mathrm{C}$ (Scheme 23). ${ }^{27 \mathrm{~b}} p$-Methoxybenzaldehyde 46 was regenerated from corresponding ethanediyl $S, S$-acetals 45 under the experimental conditions in good yields. The presence of ester, ether and hydroxyl groups in thioacetal or thioketal compounds do not interfere with the deprotection process. The author previously also demonstrated that Amberlyst-15 is an excellent and far superior catalyst for regeneration of carbonyl compounds from nitrogeneous derivatives, ${ }^{27 \mathrm{c}}$ like tosylhydrazones, oximes, 2,4-dinitrophenylhydrazones and semicarbazones when wet acetone is used as exchange reagent.

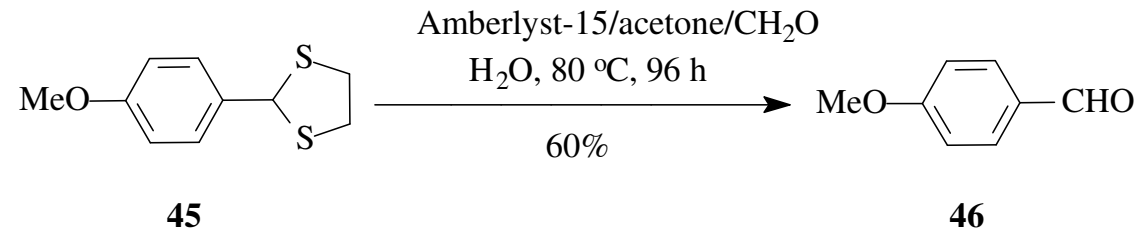

\section{Scheme 23}

\subsubsection{Hydrolysis of aromatic acetates}

Aromatic acetates of the type $\mathbf{4 7}$ were selectively deprotected to the corresponding phenols $\mathbf{4 8}$ using Amberlyst-15 as catalyst in methanol at room temperature (scheme 24). ${ }^{27 \mathrm{~d}}$ Alkyl acetates were unaffected by the catalyst. Ethers, esters and lactones functionality present in acetate compounds also remained unchanged under this reaction condition.

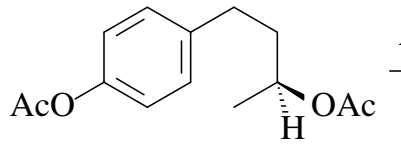

47

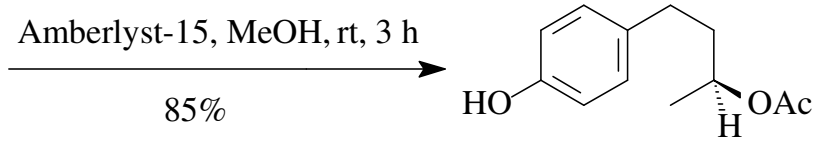

48

\section{Scheme 24}

\subsubsection{Deprotection of Boc-protected amines}

$\mathrm{Lu}$ and his groups demonstrated that the strongly acidic ion-exchange resin Amberlyst-15, effectively deprotects, purifies, and isolates BOC-protected amine compounds. Both primary and 
secondary BOC-protected aliphatic amines can be deprotected effectively with reaction times that ranged from 4 to 29 hours at ambient temperature. The presence of other functional groups such as alcohols esters and carboxylic acids do not interfere with the deprotection process. However, BOC-protected aromatic amines react slowly than the aliphatic ones (Scheme 25). ${ }^{27 \mathrm{e}}$

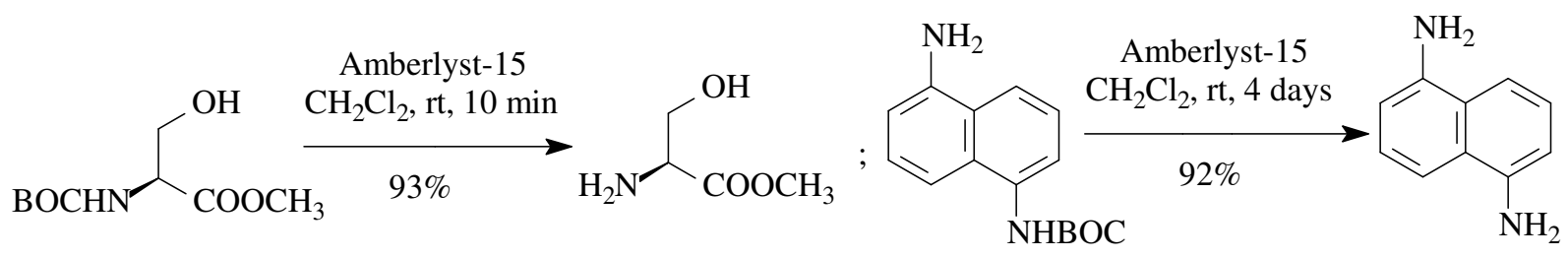

\section{Scheme 25}

\section{Epoxide Ring Opening Reaction}

Epoxides are versatile and important intermediates in organic synthesis. They undergo ringopening reactions to give $\beta$-substituted alcohols with a variety of nucleophilic species. ${ }^{28 \mathrm{a}-\mathrm{d}}$

Vijender et. al. reported that epoxides undergo rapid ring-opening reaction with various amines catalyzed by Amberlyst-15 under mild conditions to afford the corresponding $\beta$-amino alcohols in excellent yields (Scheme 26). ${ }^{29 a}$ The epoxide ring-opening occurs in a high regioselective manner with the attacking of nucleophile either at the more hindered carbon or the terminal carbon of the epoxide.

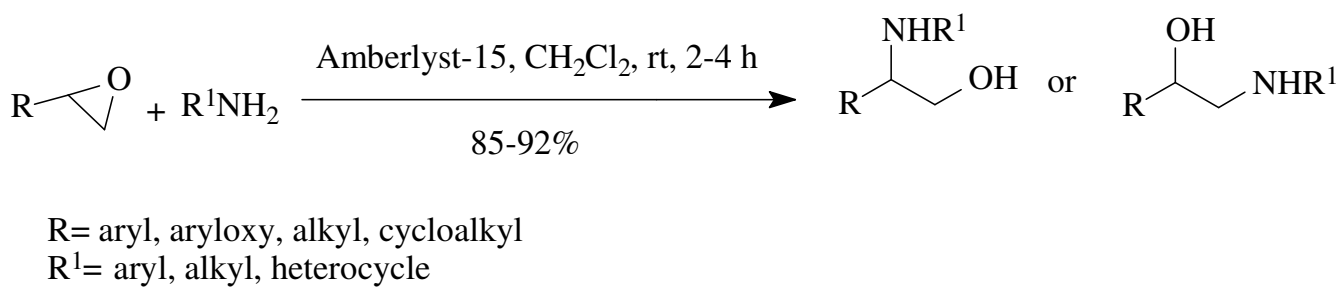

\section{Scheme 26}

Various $\beta$-alkoxy alcohols were synthesized in good to excellent yields using Amberlyst-15 catalyzed regioselective ring opening reaction of epoxide by primary, secondary and tertiary alcohols under ultrasound irradiation (Scheme 27). ${ }^{29 \mathrm{~b}}$ The likely role of Amberlyst-15 is to act as a Bronsted acid in this case for the activation of epoxide and render the epoxide more susceptible to nucleophilic attack by alcohols. Methanol gave the best yield among the alcohols used for this 
reaction. As the alkyl group of alcohol becomes bulkier, the yield of the ring-opening reaction gradually decreases.

$$
\begin{aligned}
& \mathrm{R}+\mathrm{R}^{1} \mathrm{OH} \underset{40-95 \%}{\mathrm{Amberlyst}-15, \mathrm{US}, \mathrm{rt}, 30-210 \mathrm{~min}} \\
& \begin{array}{l}
\mathrm{R}=\mathrm{CH}_{2} \mathrm{OC}_{6} \mathrm{H}_{5} ; \mathrm{CH}_{2} \mathrm{Cl} ; \text { cycloalkyl } \\
\mathrm{R}^{1}=\mathrm{CH}_{3} ; \mathrm{C}_{2} \mathrm{H}_{5} ; \mathrm{CH}\left(\mathrm{CH}_{3}\right)_{2} ; \mathrm{C}\left(\mathrm{CH}_{3}\right)_{3}
\end{array}
\end{aligned}
$$

\section{Scheme 27}

Solladie-Cavallo and his group demonstrated that Amberlyst-15 can act as an effective acid catalyst for regio- and stereoselective ring opening of 2,3-diaryl oxiranes by $\mathrm{LiBr}$ ( $\mathrm{Scheme}$ 28). ${ }^{29 \mathrm{c}}$ In the case of symmetrical trans-stilbene oxide, the syn-versus anti-bromohydrins ratio ranged between $88 / 12$ and $30 / 70$, by varying the reaction temperature from 20 to $-30{ }^{\circ} \mathrm{C}$. In the case of nonsymmetrical para-substituted trans-2,3-diaryloxiranes $\mathbf{4 9}$, the regioselectivity is

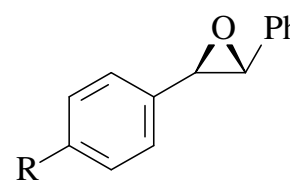

49

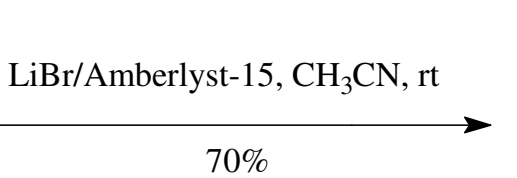

$70 \%$

$\mathrm{R}=\mathrm{NO}_{2}, \mathrm{CF}_{3}$

$$
\mathrm{R}=\mathrm{OCH}_{3}
$$

\section{Scheme 28}

determined by electronic effects. If one phenyl bears a strong electron withdrawing group $\left(\mathrm{NO}_{2}\right.$ or $\mathrm{CF}_{3}$ ), the nucleophilic attack takes place totally on the $\beta$-carbon with respect to the substituted phenyl ring to produce 50. The regioselectivity was reversed if one phenyl contains strong electron realeasing group $\left(\mathrm{OCH}_{3}\right)$ to give $\mathbf{5 1}$. 


\section{Condensation Reaction}

Cross-aldol condensation of aldehydes with ketones is an important synthetic reactions for the synthesis of $\alpha, \beta$-unsaturated carbonyl compounds, which are known to show diverse biological activities. $^{30 \mathrm{a}-\mathrm{c}}$ These types of compounds are used as intermediates for synthesis of various pharmaceuticals, agrochemicals and perfumes. ${ }^{31 a, b}$ On the other hand condensation of carbonyls and indoles give bis(3-indolyl)methanes that show a wide variety of biological activities. ${ }^{32}$ It was found that Amberlyst-15 effectively catalyses both types reactions.

\subsection{Crossed-aldol condensation reaction}

Pal and his co-workers showed that Amberlyst-15 can act as an efficient heterogeneous acid catalyst for the cross-aldol condensation reaction under solvent free conditions. Thus, when various aldehydes and ketones were mixed thoroughly with Amberlyst-15 and neutral alumina, and the mixture were subjected to microwave irradiation, the condensation products $\mathbf{5 2}$ and $\mathbf{5 3}$ were produced smoothly in very good yields (Scheme 29 and 30). ${ }^{33 a} \alpha, \alpha^{\prime}$-Bis(arylmethylene)cycloalkanones 52, $\alpha$-cinnamylideneacetophenones $53 \mathrm{a}$ and chalcones $\mathbf{5 3 \mathbf { b }}$ were produced in this process.

Mandal et al. reported that E-3-Arylidenechroman-4-ones 54a, E-3-arylidene-thiochroman-4ones 54b, E-3-cinnamylidenechroman-4-ones 55a, and E-3-cinnamylidenethiochroman-4-ones 55b could be synthesized by the reaction between different aromatic aldehydes including cinnamaldehyde and chroman-4-ones or 1-thiochroman-4-ones in presence of Amberlyst-15 under microwave irradiation in solvent-free condition in good yield (Scheme 31 and 32). ${ }^{33 \mathrm{~b}}$

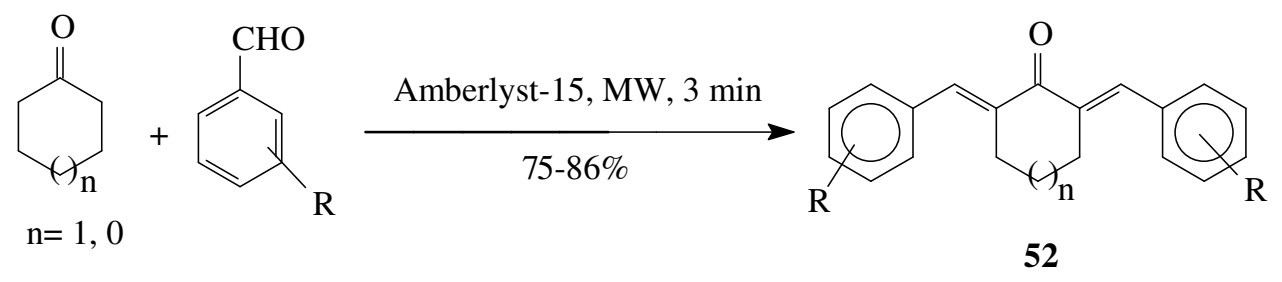

\section{Scheme 29}


<smiles>[R]C1CC2CCC([R])(C1)C2C=CC=O</smiles>

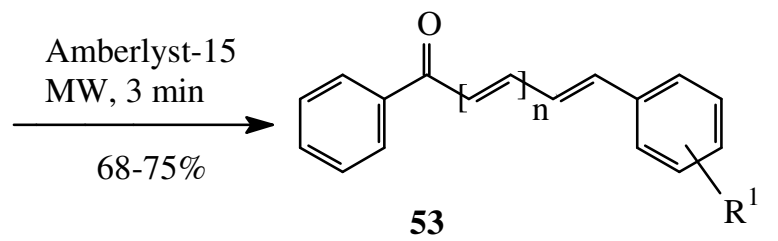

a: $\mathrm{n}=1 ; \mathbf{b}: \mathrm{n}=0$

\section{Scheme 30}

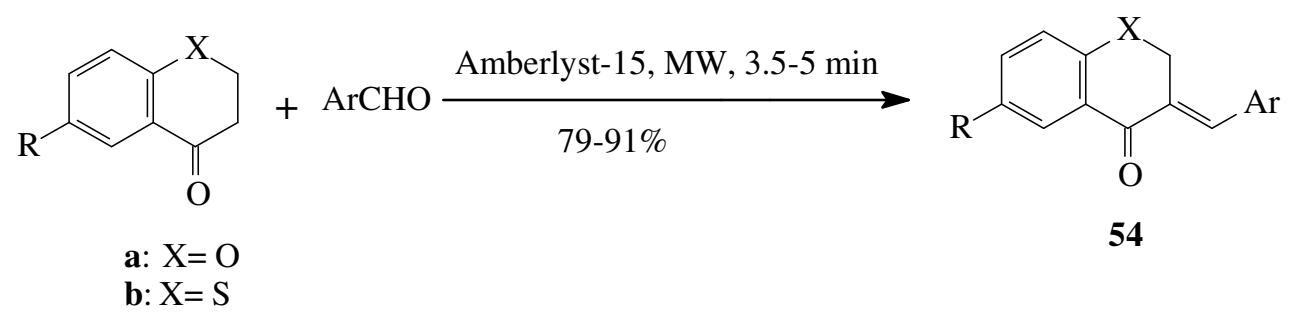

\section{Scheme 31}<smiles>[R]c1ccc([X])c(C(=O)CCC)c1</smiles>

a: $\mathrm{X}=\mathrm{O}$

b: $X=S$
Amberlyst-15, MW, 5 min $78-88 \%$<smiles>[X]c1ccc2c(c1)C(=O)/C(=C/C=C/c1ccccc1)CC2[X]</smiles>

55

\section{Scheme 32}

\subsection{Condensation of carbonyl compounds and indoles}

Ramesh and coworkers observed that of Amberlyst-15 can be utilized for the condensation of indoles with carbonyl compounds for the synthesis of bis- and tris( $1 H$-indol-3-yl)methanes 56. Thus, when Amberlyst-15 was added to a stirring solution of indole and carbonyl compounds in $\mathrm{CH}_{2} \mathrm{Cl}_{2}$ at room temperature, 56 was formed in high yield within 2-3 hrs. (Scheme 33). ${ }^{34 \mathrm{a}}$

The same condensation reaction was reported by Ke et al. ${ }^{34 \mathrm{~b}}$ using acetonitrile as solvent. 


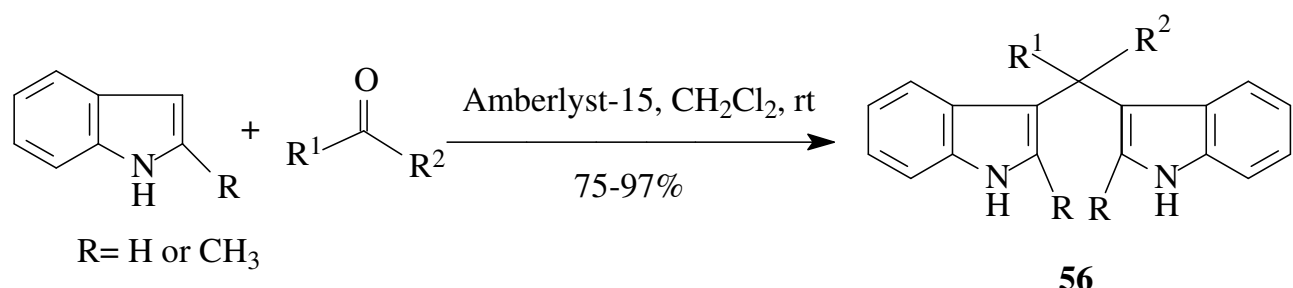

\section{Scheme 33}

Tri(heteroaryl)methanes were synthesized by Farhanullah and his group by the condensation of indoles with 4-formyl pyrazoles 57 and bis-(4-formylphenoxy)alkanes 59 separately, in $\mathrm{CHCl}_{3}$ at room temperature using Amberlyst-15 to give indole-pyrazole 58 and indole-oxyaryl 60 respectively (Figure 2). ${ }^{34 \mathrm{c}}$ The method is concise and economic at the same time.

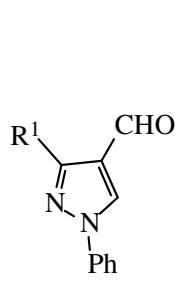

57

$\mathrm{R}^{1}=$ Aryl, $\mathrm{R}=\mathrm{H}, \mathrm{Me}$; Yield: $77-96 \%$

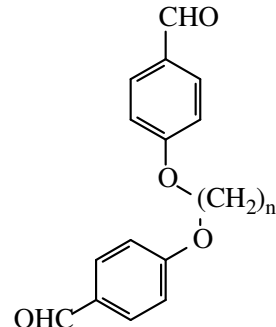

59

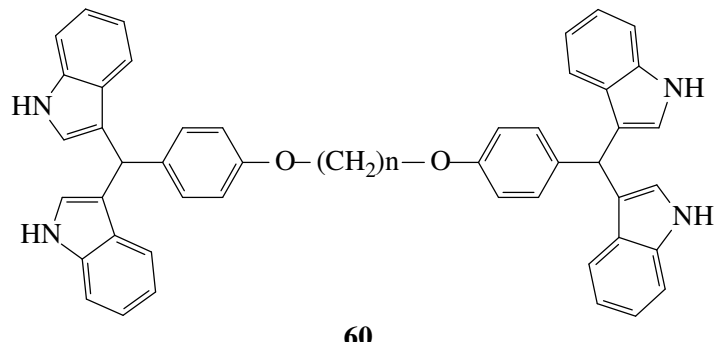

$\mathrm{n}=2$; Yield: $78 \%$ $\mathrm{n}=3$; Yield: $84 \%$

\section{Figure 2}

\section{Multicomponent Reaction}

Multicomponent reactions have recently gained much practical importance due to their speed, diversity and efficiency. ${ }^{35 a-c}$ Das and Reddy reported an efficient one-pot multicomponent synthesis of $\beta$-acetamido ketones $\mathbf{6 1}$ from aromatic aldehydes, enolizable ketones or keto esters and both acetyl chloride $(\mathrm{AcCl})$ and acetonitrile $(\mathrm{MeCN})$ at room temperature using Amberlyst15 as catalyst (Scheme 34). ${ }^{36 a}$ Aromatic aldehydes containing either electron-donating or withdrawing groups underwent the conversion smoothly. Several functional groups such as halogen $(\mathrm{Cl}, \mathrm{Br}), \mathrm{NO}_{2}$, ester and ether moieties were found to be stable under the reaction condition. Compared with the other methods for multicomponent synthesis of $\beta$-acetamido ketones, this new method using Amberlyst-15 offers better yields, shorter reaction times and economic viability. 


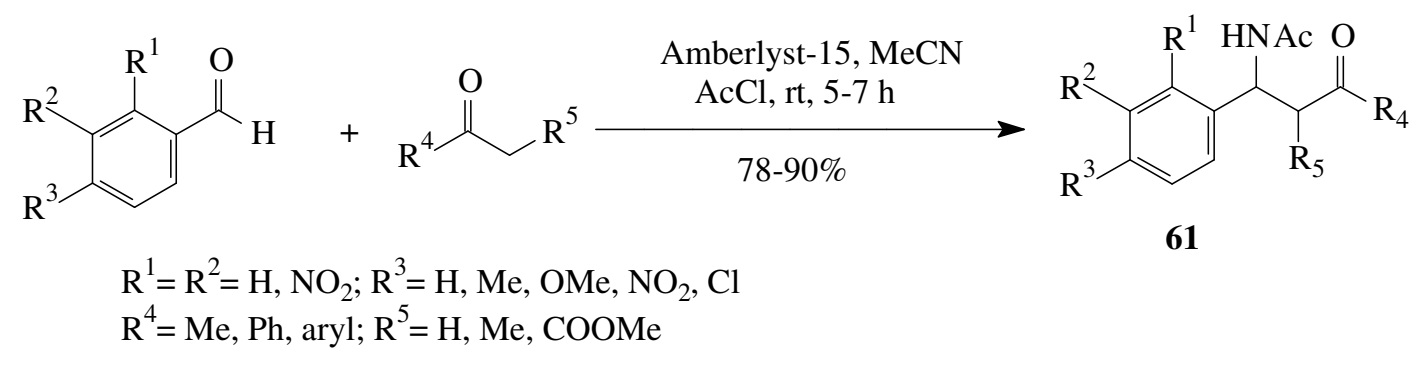

\section{Scheme 34}

A similar single-step multicomponent reaction has been reported for the coupling of anthranilic acid, orthoesters and amines to their corresponding 4(3H)-quinazolines 62, using a catalytic amount of Amberlyst-15 under solvent-free conditions (Scheme 35). ${ }^{36 \mathrm{~b}}$

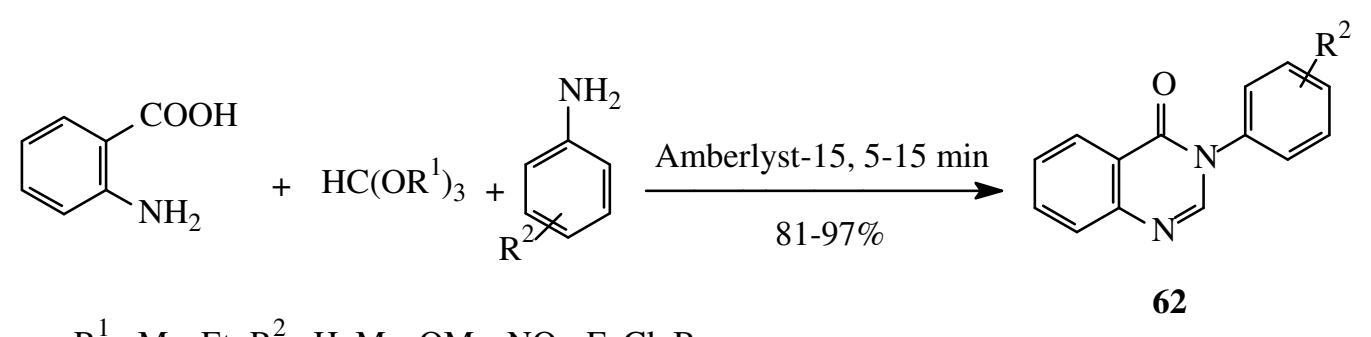

$\mathrm{R}^{1}=\mathrm{Me}, \mathrm{Et} ; \mathrm{R}^{2}=\mathrm{H}, \mathrm{Me}, \mathrm{OMe}, \mathrm{NO}_{2}, \mathrm{~F}, \mathrm{Cl}, \mathrm{Br}$

\section{Scheme 35}

\section{Formation of Nitrogen Heterocycles}

Nitrogen heterocycles form the backbone for a host of biologically active molecules. Quinoline $^{37 a, b}$ and pyrazoline ${ }^{38 a-c}$ systems are known to be important constituents of many pharmaceutical and agrochemical products. Indoline-3-ones have been used for chromogenic detection of esterase activity. ${ }^{39 a, b}$ Acridine derivatives are interesting chemotherapeutic having antibacterial and antiparasite properties. ${ }^{40}$ Calix[4]pyrroles are conformationally flexible macrocycles ${ }^{41 \mathrm{a}}$ of significant importance due to their binding property with anions ${ }^{41 \mathrm{~b}}$ neutral substrates $^{41 \mathrm{c}}$ and metal ions ${ }^{41 \mathrm{~d}}$ under different reaction conditions. These important nitrogeneous heterocycles have efficiently been synthesized using heterogeneous solid acid catalyst, Amberlyst-15. 


\subsection{Synthesis of quinolines}

A series of substituted quinolines $\mathbf{6 3}$ were synthesized by Das et al. from the reaction between 2aminoaryl ketones and $\alpha$-methylene carbonyl compounds using Amberlyst-15, a heterogeneous solid acid catalyst (Scheme 36). ${ }^{42 a}$ The catalyst was found to be most effective for the synthesis of quinolines in terms of reaction times, yields and reusability, over the other heterogeneous solid acid catalysts like $\mathrm{NaHSO}_{4}-\mathrm{SiO}_{2}, \mathrm{H}_{2} \mathrm{SO}_{4}-\mathrm{SiO}_{2}$ and $\mathrm{HClO}_{4}-\mathrm{SiO}_{2}$.

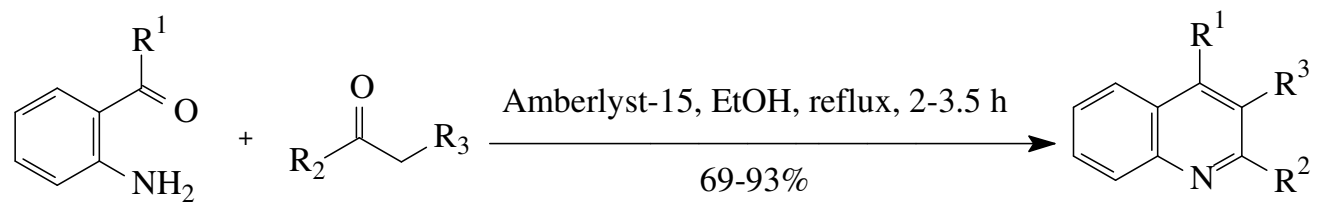

63

\section{Scheme 36}

Hou and coauthors reported a simple and reliable method for the direct synthesize of quinolines 64 from 2-aminobenzophenone and arylketones in ionic liquid [Bimn][ $\left.\mathrm{PF}_{6}\right]$ using Amberlyst-15 as catalyst (Scheme 37$){ }^{42 b}$

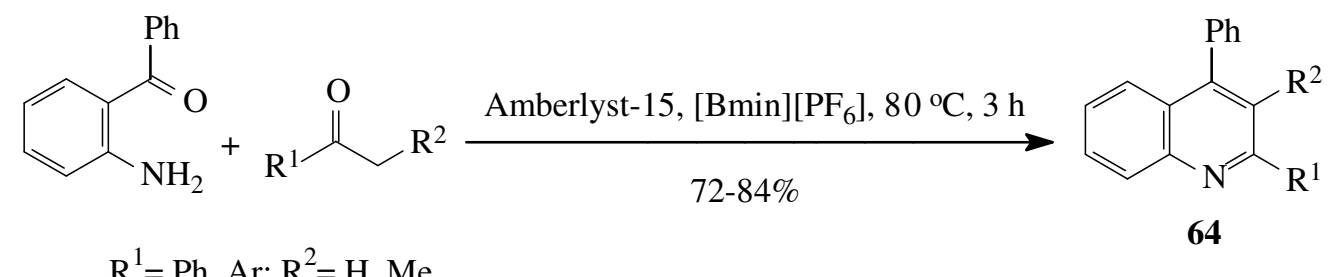

\section{Scheme 37}

Dioxoloquinolonone derivatives 66 were synthesized by Abonia and his groups using Amberlyst-15 as catalyst. When various 2'-amino[1,3]dioxolochalcones 65 were dissolved in acetic acid and stirred at $80{ }^{\circ} \mathrm{C}$ in the presence of Amberlyst-15, the corresponding dihydroquinolin-8-ones were isolated in good to excellent yields (Scheme 38). ${ }^{42 \mathrm{c}}$ 
<smiles>Nc1cc2c(cc1C(=O)/C=C/[13I])OCO2</smiles>

65
Amberlyst-15, $\mathrm{AcOH}, 80^{\circ} \mathrm{C}, 4 \mathrm{~h}$ $78-98 \%$<smiles>O=C1CC([Al])Nc2cc3c(cc21)OCO3</smiles>

66

\section{Scheme 38}

\subsection{Synthesis of pyrazolines}

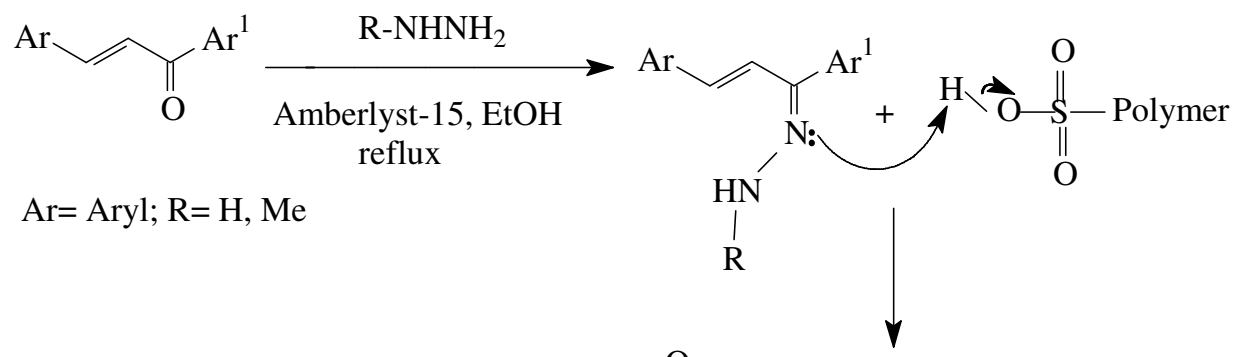

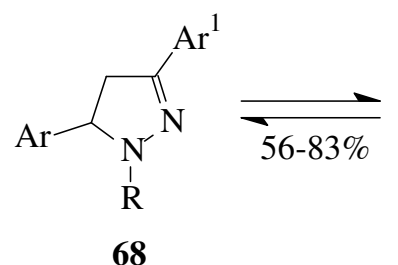

68

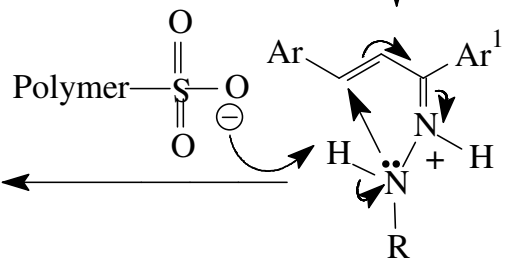

67

\section{Scheme 39}

Pyrazolines, a biologically active and an important constituent of many pharmaceutical and agrochemical products were synthesized by Hola and his groups using Amberlyst-15. Thus, when chalcones were treated with hydrazine or substituted hydrazines in presence of Amberlyst15 in refluxing toluene the substituted pyrazolines 68 were produced in good yields (Scheme 39). ${ }^{43}$ The proposed reaction mechanism involves a 5-endo-trig cyclization of the intermediate 67. 


\subsection{Synthesis of indolin-3-ones}

2'-Aminochalcone 69 derived from 4-pyridinecarboxaldehyde undergoes intramolecular cyclization in presence of Amberlyst-15/AcOH media. Unexpectedly, the reaction proceeded through a 5-exo process thus providing an alternative approach for the synthesis of 2(pyridinylmethylene)indolin-3-one 73 (Scheme 40). ${ }^{44}$ The key step is the formation of resonant species 70, where the ipso carbon atom of the pyridine ring, rapidly acquire a positive charge after the protonation of the basic pyridine nitrogen atom. This species $\mathbf{7 0}$ is also stabilized via an exocyclic allylic type cation, which favors the 5-exo attack of the amino group towards the $\alpha$ position of $\mathbf{7 0}$ producing the species $\mathbf{7 1}$ which rapidly tautomerizes to structure $\mathbf{7 2}$. A subsequent dehydration of the intermediate $\mathbf{7 2}$ generated $\mathbf{7 3}$.

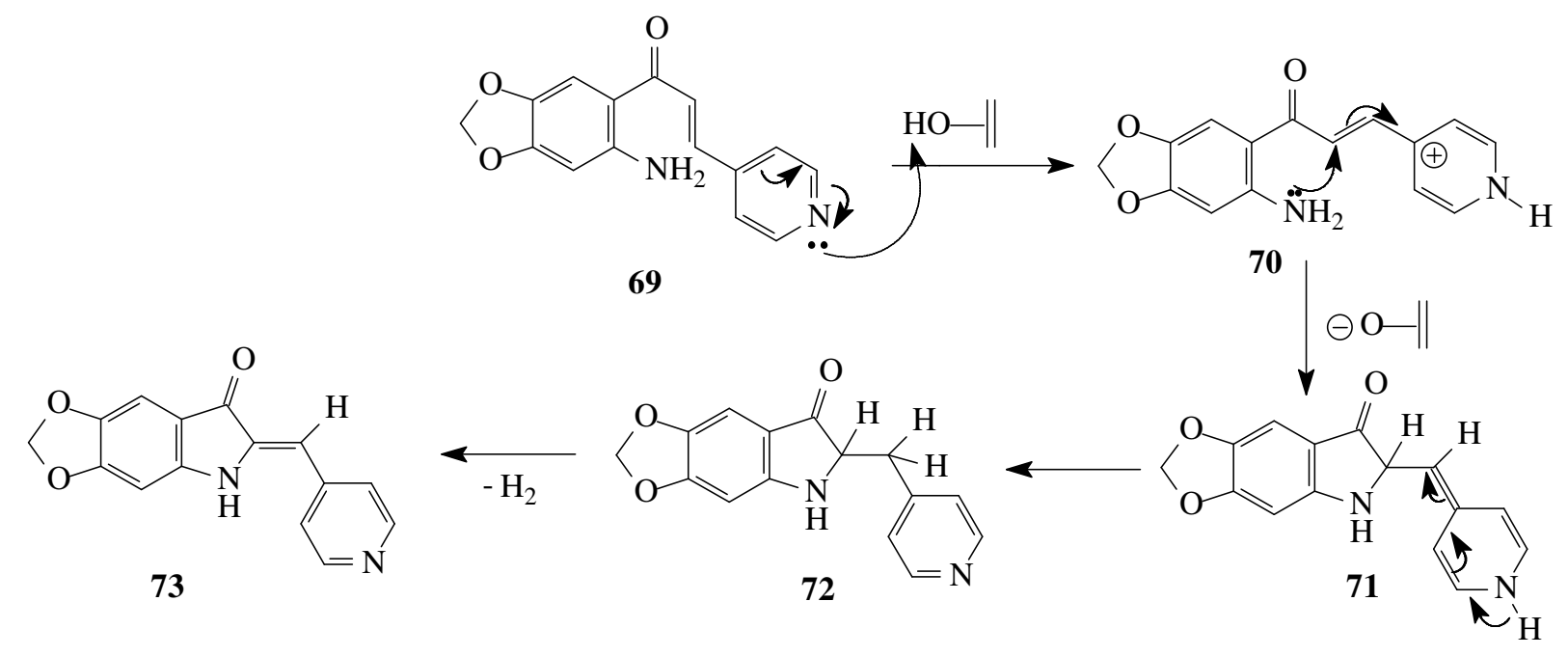

\section{Scheme 40}

\subsection{Synthesis of 1,8-dioxodecahydroacridines}

Das and co-workers have reported that Amberlyst-15 acts as an excellent catalyst for the synthesis of 1,8-dioxodecahydroacridines 74, a class of tricyclic nitrogeneous heterocyclic compounds. When amines and 5,5-dimethyl-1,3-cyclohexedione were refluxed in $\mathrm{CH}_{3} \mathrm{CN}$ in presence of Amberlyst-15 for a specified time, 74 was furnished in excellent yields (Scheme 41). ${ }^{45}$ Aromatic and aliphatic amines underwent the conversion with same efficiency. 


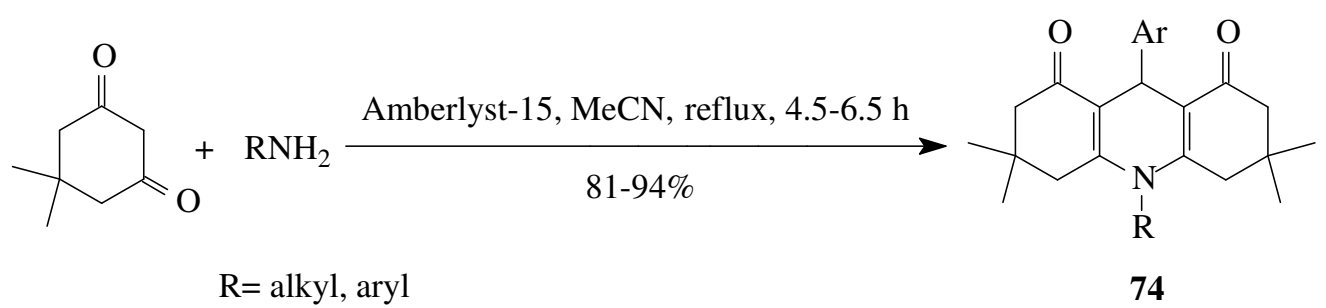

\section{Scheme 41}

\subsection{Synthesis of calix[4]pyrroles}

A facile and efficient protocol was reported by Chauhan et al. for the synthesis of calix[4]pyrroles 75, and $N$-confused calix[4]pyrroles $\mathbf{7 6}$ in moderate to excellent yields by reaction of dialkyl or cycloalkyl ketones, catalyzed by Amberlyst-15 under eco-friendly conditions (Scheme 42). ${ }^{46}$

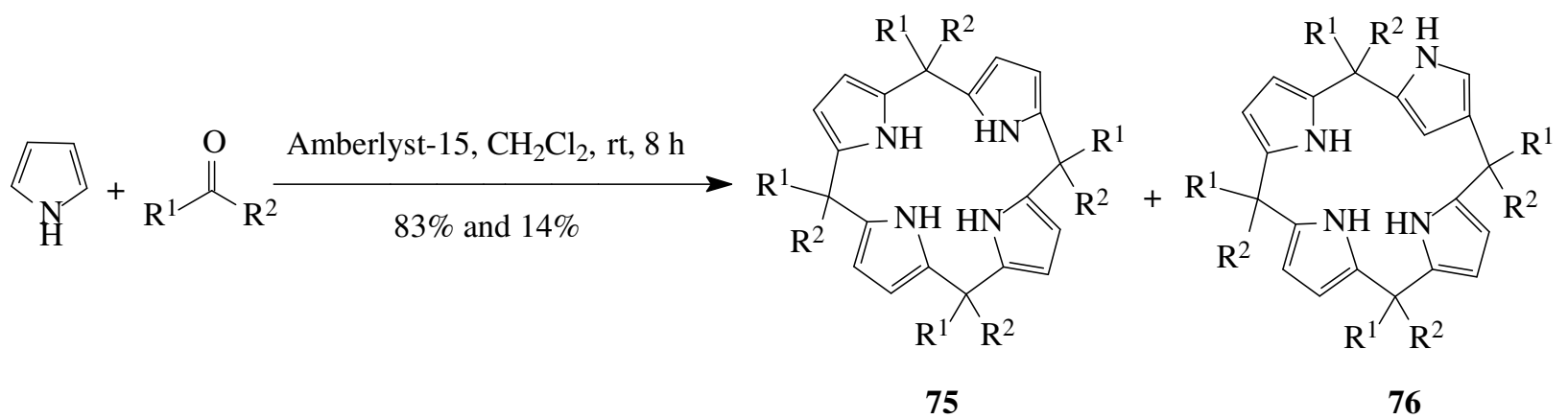

\section{Scheme 42}

\section{Formation of Oxygen Heterocycles}

Oxygen heterocycles also represent a very important class of biologically active compounds. Xanthenes show antiviral, antibacterial activities, ${ }^{47 a, b}$ coumarins find applications as fragrances and pharmaceuticals. ${ }^{48 a, b}$ On the other hand benzopyrans form the backbone of many natural products and is also present in the recently discovered HIV inhibitory class of benzotripyrans. ${ }^{4 a, b}$ Moreover, theaspiranes form the aroma components in tea and functionalized 
furan derivatives are the structural moieties in many bioactive natural products and important pharmaceuticals. $^{50 \mathrm{a}, \mathrm{b}}$ These oxygen heterocycles may be synthesized by using Amberlyst-15 as catalyst.

\subsection{Synthesis of xanthenes}

Ko and Yao developed a simple and reliable method for the direct construction of biologically active 14-substituted-14H-dibenzo[ $a, j]$ xanthenes 77 in high yield from a one-pot condensation of $\beta$-naphthol with aldehydes in presence of Amberlyst-15 under solvent-free conditions (Scheme 43). ${ }^{51}$ The mechanism of this reaction includes the initial generation of the carbocation, followed by the formation of aryl- or alkyl-methanebisnaphthols, which then undergo dehydration to give the final product.

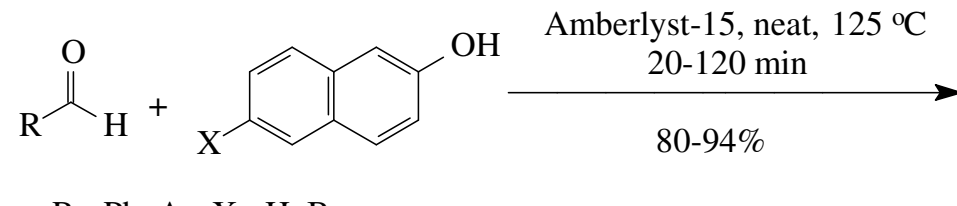

$$
\mathrm{R}=\mathrm{Ph}, \mathrm{Ar} ; \mathrm{X}=\mathrm{H}, \mathrm{Br}
$$<smiles></smiles>

77

\section{Scheme 43}

Das et al. have demonstrated that Amberlyst-15 acts as an excellent catalyst for the synthesis of 1,8-dioxo-octahydroxanthenes 78, a tricyclic oxygen heterocycle. When an aldehyde and 5,5dimethyl-1,3-cyclohexedione were refluxed in $\mathrm{CH}_{3} \mathrm{CN}$ in presence of Amberlyst-15 for specified time, 78 was furnished in excellent yield (Scheme 44). ${ }^{45}$

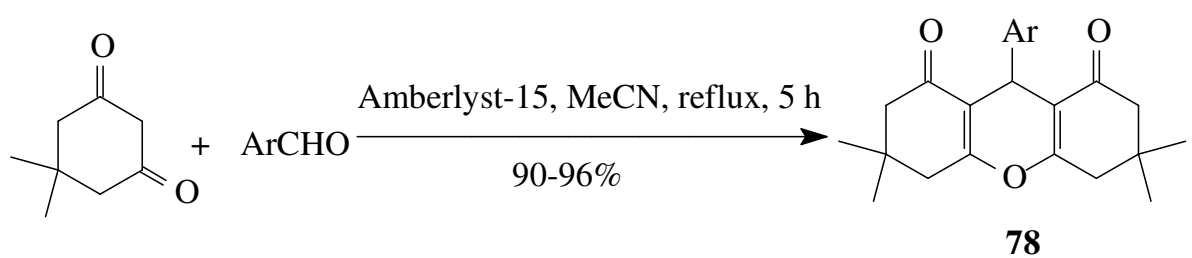

\section{Scheme 44}




\subsection{Synthesis of coumarins}

Sabou et al. worked on the synthesis of 7-hydroxy-4-methylcoumarin 79 via the Pechman reaction of resorcinol and ethyl acetate over various Amberlyst-type catalysts, such as Amberlyst-Cl, Amberlyst-15, Amberlyst-35, Amberlyst-36 and Amberlyst-S. Amongst these Amberlyst-15 afforded 79 with 95\% conversion and 92\% selectivity in refluxing toluene after 2 hrs. of reaction time at $120^{\circ} \mathrm{C}$ (Scheme 45). ${ }^{52}$ However, the new catalysts, such as Amberlyst-Cl and Amberlyst-S materials showed better activity and were more stable than Amberlyst-15.

Amberlyst-15 catalyzed synthesis of 7-hydroxy-3,4-dihydrocoumarin from resorcinol and propenoic acid in toluene was reported by Gunnawegh et al. (Scheme 46). ${ }^{53}$ The probable mechanism involves esterification followed by alkylation (ring closure) activated by Amberlyst15.

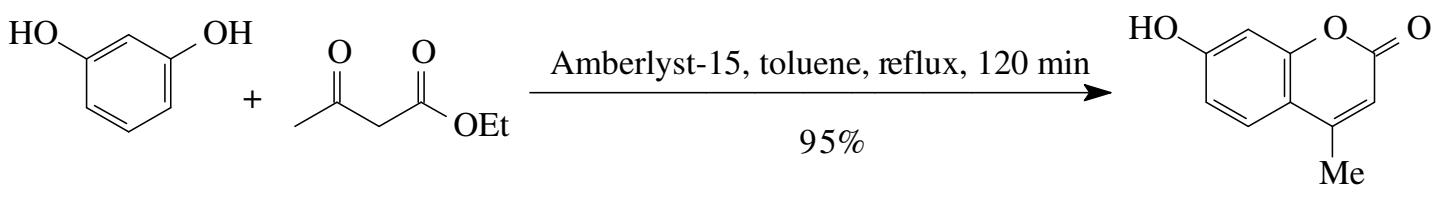

\section{Scheme 45}

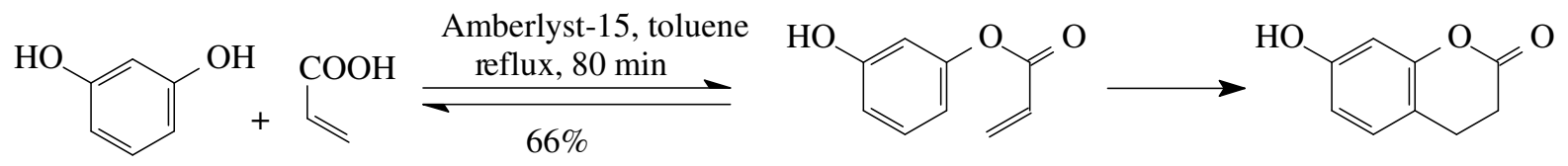

\section{Scheme 46}

\subsection{Synthesis of benzopyrans}

Kalena and his groups demonstrated that Amberlyst- 15 has been utilized as solid acid catalyst for the synthesis of benzopyrans via prenylation of phenolics. 2,2-Dimethyl-6-hydroxychroman $\mathbf{8 0}$ and 2,2-dimethyl-6-hydroxychromene $\mathbf{8 1}$ were synthesized from the reaction of hydroquinone with 2-methyl-1,3-butadiene and 3-hydroxy-3-methylbut-1-yne respectively (Scheme 47) ${ }^{54}$ using Amberlyst-15. 

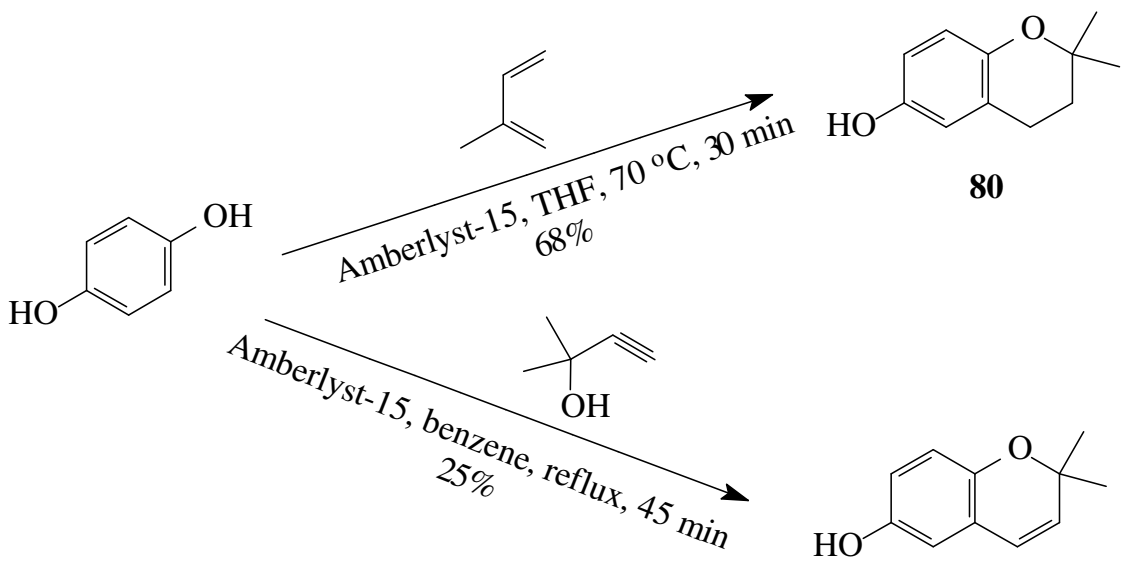

81

\section{Scheme 47}

Pyranopyran derivatives were synthesized by Talinli et al. using Amberlyst-15 in the reaction between 2-naphthol and dimethylol ketones 82 (Scheme 48). ${ }^{55}$ The first step involves the production of ketodinaphthol $\mathbf{8 3}$ by condensation of 2-naphthol and 82, which undergoes intramolecular acetalization reaction to afford the pyranopyran 84 in the second step.

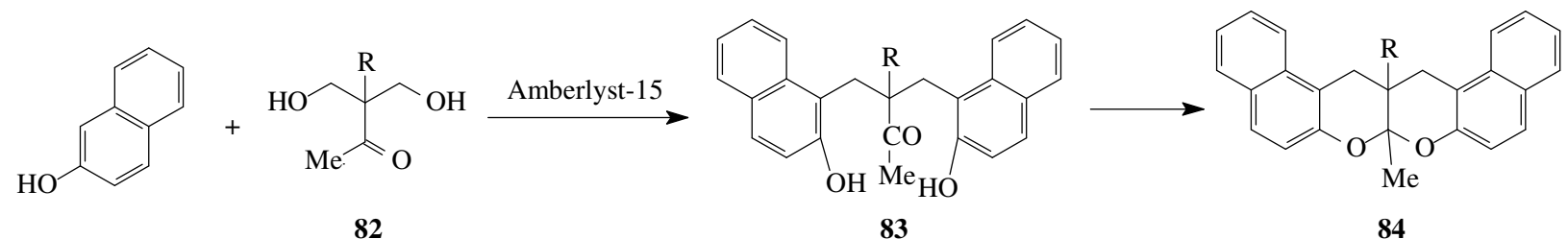

\section{Scheme 48}

\subsection{Synthesis of theaspirane}

Young et al. demonstrated that the route for Amberlyst-15 catalyzed intramolecular oxaspirocyclization of secondary allylic alcohol $\mathbf{8 5}$, can be applied to the synthesis of theaspirane $\mathbf{8 6}$, an allylic oxaspirocycles, to give high yields of the product (Scheme 49). ${ }^{56}$ 


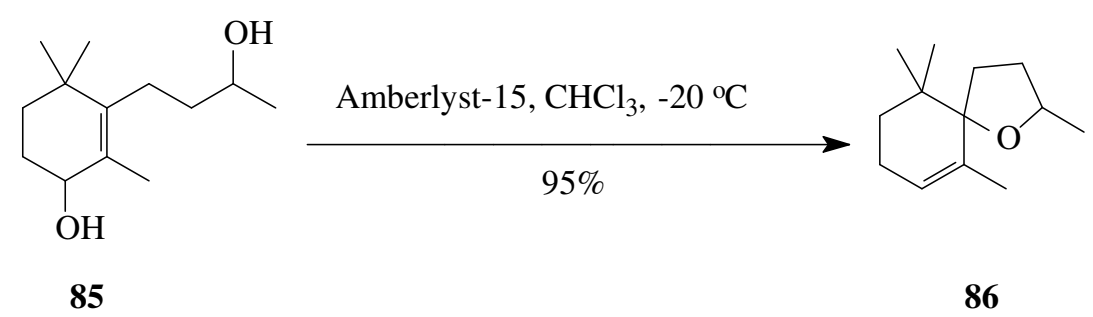

\section{Scheme 49}

\subsection{Synthsis of furan derivatives}

Amberlyst-15 has also been used for the synthesis of furan derivatives. Palmieri and his group have synthesized a series of disubstituted furan derivatives $\mathbf{8 9}$ from functionalized nitroalkane $\mathbf{8 7}$ with the aldehydes $\mathbf{8 8}$ in ethyl acetate using successive Amberlyst-A21 and Amberlyst-15 catalyzed processes (Scheme 50). ${ }^{57}$

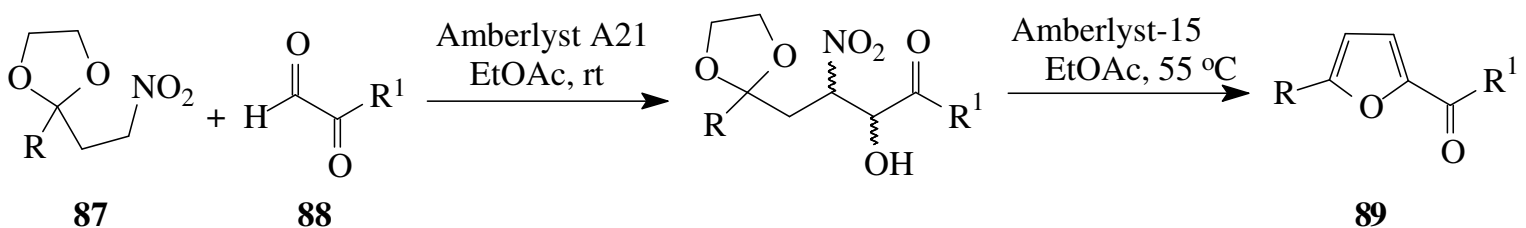

\section{Scheme 50}

\section{Synthesis of Homocyclic Compounds}

Fused homocyclic compounds 91, were also synthesized by using Amberlyst-15. Schinzer et al. reported that additions of propargylicsilanes $\mathbf{9 0}$ to enones or ene-ketones can be achived in a simple fashion using Amberlyst-15 (Scheme 51) ${ }^{58}$. A non-aqueous work-up and room temperature conditions makes this novel cyclization technique very attractive for sensitive cyclization substrates. 


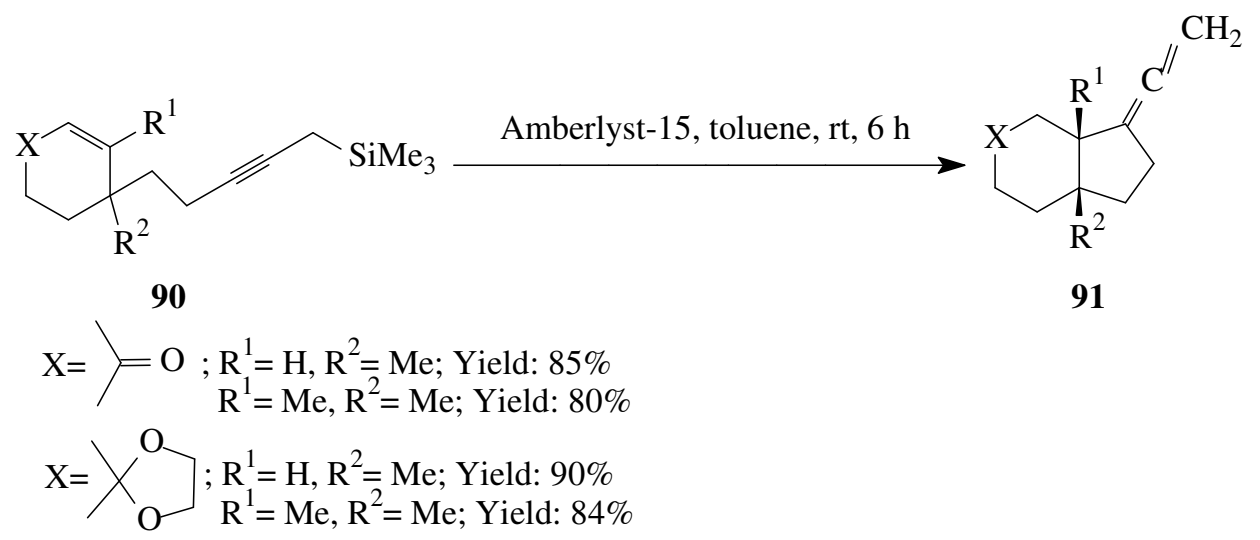

\section{Scheme 51}

\section{Synthesis of Substituted Phosphonates}

Phosphorus-carbon [P-C] bond formation reactions ${ }^{59 \mathrm{a}-\mathrm{d}}$ have drawn much interest in recent times. Substituted phosphonates such as $\alpha$-hydroxy phosphonates, ${ }^{60 a, b}$ sulphonamido-phosphonates, ${ }^{61 \mathrm{a}-\mathrm{c}}$ and alkyl/aryl/heteroaryl phosphonates ${ }^{62}$ are the pentavalent phosphorus compounds of considerable synthetic interest due to their utility as reagents in several reactions, and also for their applications in bioorganic and pharmacological fields.

\subsection{Synthesis of $\alpha$-hydroxy phosphonates}

Tajbakhsh and coauthors have developed an efficient procedure for synthesis of $\alpha$-hydroxy phosphonates 92 from aldehydes and trimethyl phosphite using Amberlyst-15 in water (Scheme 52). ${ }^{63}$ Probably, the solid acid catalyst, Amberlyst-15 generates a hydronium ion in water that activates the carbonyl group, which consequently undergoes nucleophilic attack by trialkyl phosphite. Water was found to be the most appropriate solvent over the other organic solvents such as diethyl ether, $\mathrm{CH}_{2} \mathrm{Cl}_{2}, \mathrm{CHCl}_{3}, \mathrm{MeCN}$, THF and $\mathrm{MeOH}$, in respect of yields. 


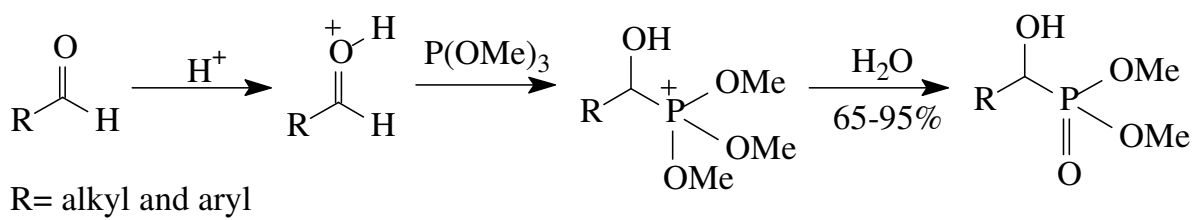

92

\section{Scheme 52}

\subsection{Synthesis of sulphonamido-phosphonates}

Very recently, Sudhakar and his group have reported the preparation of sulphonamidophosphonates 93 from $N$-tosyl aldimines and dimethyl trimethylsilyl phosphate at $0{ }^{\circ} \mathrm{C}$ in presence of Amberlyst-15 as a heterogeneous catalyst (Scheme 53). ${ }^{64}$

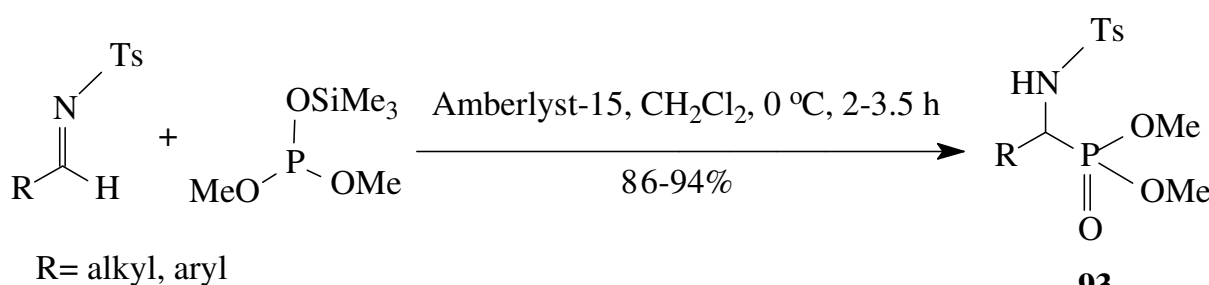

\section{Scheme 53}

\subsection{Synthesis of alkyl/aryl/allyl/heteroaryl phosphonates}

A new and convenient procedure for the synthesis of alkyl/aryl/allyl/heteroaryl phosphonates 94 using Amberlyst-15 under solvent-free conditions was developed by Kundu et al. (Scheme 54). ${ }^{65}$ This solvent-free protocol is highly efficient and affords the product in excellent yields with high purity. 


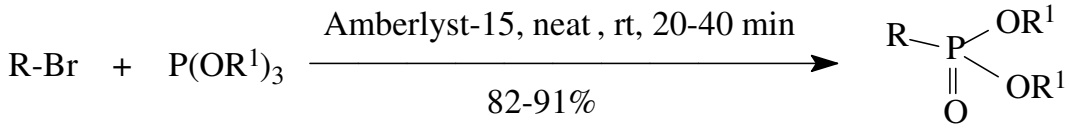

$$
\begin{aligned}
& \mathrm{R}=\text { alkyl, allyl, aryl and heteroaryl } \quad 94 \\
& \mathrm{R}^{1}=\mathrm{Et}, \mathrm{Ph}
\end{aligned}
$$

\section{Scheme 54}

\section{Synthesis of $\beta$-Enaminones and $\beta$-Enaminoesters}

The $\beta$-enaminone derivatives are very useful synthons for the synthesis of various active heterocyclic compounds which exihibits a wide range of biological activities. ${ }^{66 a-d}$ Narsaiah et al. reported that Amberlyst-15 can be used for the synthesis of $\beta$-enaminones and $\beta$-enamino esters. Thus, when various $\beta$-keto carbonyls and $\beta$-keto esters were treated with different amines in presence of Amberlyst-15 at room temperature $\beta$-enaminones and $\beta$-enamino esters respectively were produced in excellent yields (Scheme 55). ${ }^{67}$

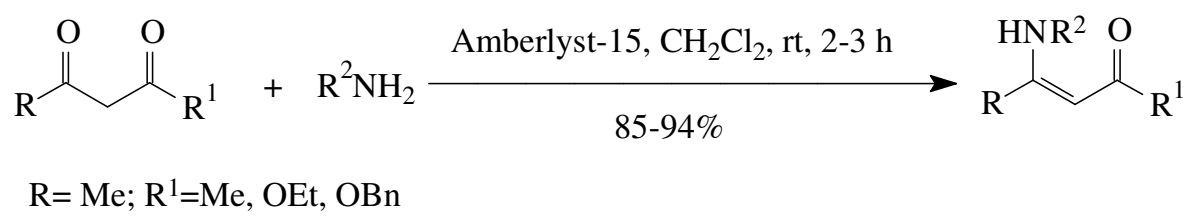

\section{Scheme 55}

\section{Conclusions}

This review demonstrates an active current interest in synthetic applications of Amberlyst-15 catalyst. This growing interest of Amberlyst-15 is mainly due to their very useful acidic properties, combined with benign environmental character, reusability and commercial availability. There has been a major surge of catalytic activity in several areas of the Amberlyst15 chemistry. These areas include the application of Amberlyst-15 acid catalysts in various organic transformations such as formation of C-C, C-N, C-P and C-S bonds in different synthetically important compounds. We anticipate that these areas of Amberlyst-15 chemistry will continue to attract significant research activity in the future. 


\section{Acknowledgements}

Our own work described here was supported by Departmental Research Grant from the Acharya J. C. Bose College.

\section{References}

1. (a) Kawabata, T.; Mizugaki, T.; Ebitani, K.; Kaneda, K. Tetrahedron Lett. 2003, 44, 9205. (b) Zatta, L.; Gardolinski, J. E. F. C.; Wypych, F. Appl. Clay Sci. 2011, 51, 165. (c) Shojaei, A. F.; Rezvani, M. A.; Baei, M. S. World Appl. Sci. J. 2010, 11, 727. (d) Khojastehnezhad, A.; Davoodnia, A.; Bakavoli, M.; Tavakoli-Hoseini, N.; Zeinali-Dastmalbaf, M. Chin. J. Chem. 2011, 29, 297. (e) Liu, J. Y.; Liu, J.; Wang, J. D.; Jiao, D. Q.; Liu, H. W. Synth. Commun. 2010, 40, 2047. (f) Bora, P. P.; Vanlaldinpuia, K.; Rokhum, L.; Bez, G. Synth. Commun. 2011, 41, 2674. (g) Chao, S. J.; Lu, G. Z.; Wu, L. Q. Asian J. Chem. 2011, 23, 3865. (h) Chari, M. A. Tetrahedron Lett. 2011, 52, 6108. (i) Lenin, R.; Raju, R. M. Lett. Org. Chem. 2010, 7, 392.

2. (a) Izci, A.; Hosgun, H. L. Truk J. Chem. 2007, 31, 493. (b) Harmer, M. A.; Sun, Q. Appl. Catal. A: Gen. 2001, 221, 45.

3. (a) Petrini, M.; Ballini, R.; Marcantoni, E. Synth. Commun. 1988, 18, 847. (b) Talukder, M. M. R.; Wu, J. C.; Lau, S. K.; Cui, L. C.; Shimin, G.; Lim, A. Energy Fuel 2009, 23, 2. (c) Chavan, S. P.; Subbarao, T.; Dantale, S. W.; Sivappa, R. Synth. Commun. 2001, 31, 289. (d) Pappu, V. K. S.; Yanez, A. J.; Peereboom, L.; Muller, E.; Lira, C. T.; Miller, D. J. Bioresource Technology, 2011, 102, 4270.

4. (a) Das, B.; Damodar, K.; Chowdhury, N. J. Mol. Catal. A: Chem. 2007, 269, 81. (b) Bandini, M.; Fagioli, M.; Umani-Ronchi, A. Adv. Synth. Catal. 2004, 346, 545.

5. (a) Das, B.: Chowdhury, N. J. Mol. Catal. A: Chem. 2007, 263, 212. (b) Esteves, A. P.; Silva, M. E.; Rodrigues, L. M.; Oliveira-Campos, A. M. F.; Hrdina, R. Tetrahedron Lett. 2007, 48, 9040.

6. (a) Basavaiah, D.; Rao. A. J.; Satyanarayana, Chem. Rev. 2003, 103, 811. (b) Hoffmann, H. M. R.; Rabe, J. Angew. Chem., Int. Ed. Engl. 1985, 24, 94. (c) Buchholz, R.; Hoffmann, H. M. R.; Helv. Chim. Acta 1991, 74, 1213. (d) Das, B.; Banerjee, J.; Mahender, M.; Majhi, A. Org. Lett. 2004, 6, 3349.

7. (a) Das, B.; Majhi, A.; Banerjee, J.; Chowdhury, N. J. Mol. Catal. A: Chem. 2006, 260, 32.

(b) Das, B.; Banerjee, J.; Majhi, A.; Chowdhury, N.; Venkateswarlu, K.; Holla, H. Indian J. Chem. 2006, 45B, 1729.

8. (a) Adams, D. R.; Bhatnagar, S. P. Synthesis 1977, 661. (b) Chandrasekhar, S.; Reddy, B. V. S. Synlett 1998, 851 .

9. (a) Biovin, T. L. B. Tetrahedron 1987, 43, 3309. (b) Perron, F.; Albizati, K. F. J. Org. Chem. 1987, 52, 4130 . 
10. Yadav, J. S.; Reddy, B. V. S.; Sekhar, K. C.; Gunasekar, D. Synthesis 2001, 885.

11. (a) Kadam, S. T.; Thirupathi, P.; Kim, S. S. Tetrahedron 2009, 65, 10383. (b) Weissemel, K.; Arpe, H.-J. In Industrial Organic Chemistry, 3rd Edn.; VCH Weinheim: 1997, p. 358. (c) Ma, Q.; Chakraborty, D.; Faglioni, F.; Muller, R. P.; Goddard, III, W. A. J. Phys. Chem. A 2006, 110, 2246. (d) Das, B.; Veeranjaneyulu, B.; Krishnaiah, M.; Balasubramanyam, P. Synth. Commun. 2009, 39, 1929.

12. (a) Das, S. K.; Panda, G.; Chaturvedi, V.; Manju, Y. S.; Gaikwad, A. K.; Sinha, S. Bioorg. Med. Chem. Lett. 2007, 17, 5586. (b) Feixas, J.; Jimenez, J.-M.; Godessart, N.; Puig, C.; Soca, L.; Crespo. M. I. Bioorg. Med. Chem. Lett. 2001, 11, 2687. (c) Kongkathip, B.; Sangma, C.; Kirtikara, K.; Luangkamin, S.; Hasitapan, K.; Jongkon, N.; Hannongbua, S.; Kongkathip, K. Bioorg. Med. Chem. Lett. 2005, 13, 2167. (d) Narasimhan, N. S.; Mali, R. S. Tetrahedron 1975, 31, 1005. (e) Miller, B.; Lin, W.-O. J. Org. Chem. 1978, 43, 4441.

13. (a) Das, B.; Pal, R.; Banerjee, J.; Mahender, G.; Holla, H.; Venkateswarlu, K. Indian J. Chem. 2005, 44B, 198. (b) Wu, L.; Yang, C.; Zhang, C.; Yang, L. Bull. Korean Chem. Soc. 2009, 30, 1665.

14. Das, B.; Krishnaiah, M.; Laxminarayana, K.; Damoder, K.; Kumar, D. N. Chem. Lett. 2009, $38,42$.

15. 15 (a) Meshram, H. M.; Reddy, P. N.; Sadashiv, K.; Yadav, J. S. Tetrahedron Lett. 2005, 46, 623. (b) Tajbakhsh, M.; Hosseinzadeh, R.; Lasemi, Z. Synlett 2004, 635.

16. (a) Green, T. W.; Wuts, P. G. M. Protective Groups in Organic Synthesis, 2nd Edn.; Wiley: New York, 1991. b) Kocienski, P. J. Protecting Groups, 3rd Edn.; Gerog. Thieme Verlag: Stuttgart, New York, 1994, pp. 50-71.

17. (a) Greene, T. W. Protective Groups in Organic Synthesis, Wiley: New York, 1981, p. 133.

(b) Pinnick, H. W.; Kochhar, K. S.; Bal, B. S.; Deshpandey, R. P.; Rajdhayaksha, S. N. J. Org. Chem. 1983, 48, 1765.

18. (a) Villotti, R.; Djerassi, C.; Ringold, M. J. J. Am. Chem. Soc. 1959, 81, 4566. (b) Allan, J. A. V. Org. Synth. Coll. 1963, IV, 21.

19. (a) Kamitori, Y.; Hoja, M.; Masuda, R.; Kimura, T.; Yoshida, T. J. Org. Chem. 1986, 51, 1427. (b) Soderquist, J. A.; Miranda, E. I. Tetrahedron Lett. 1986, 27, 6305.

20. (a) Deke, N.; Kalita, D. J.; Borah, R.; Sarma, J. C. J. Org. Chem. 1997, 62, 1563. (b) Aggarwal, V. K.; Fonquerna, S.; Vennall, G. P. Synlett 1998, 849. (c) Chandra, K. L.; Saravanan, P.; Sinhh, V. K. Synlett 2000, 359.

21. (a) Basel, Y.; Hassner, A. J. Org. Chem. 2000, 65, 6368. (b) Darnbrough, S.; Mervic, M.; Condon, S. M.; Burns, C. J. Synth. Commun. 2001, 31, 3273.

22. (a) Patwardhan, S. A.; Dev, S. Synthesis 1974,348. (b) Perni, R. B. Synth. Commun. 1989, 19, 2383. (c) Reddy, A. V.; Ravinder, K.; Reddy, V. L. N.; Ravikanth, V.; Venkateswarlu, Y. Synth. Commun. 2003, 33, 1531. (d) Kumar, K. S.; Iqbal, J.; Pal, M. Tetrahedron Lett. 2009, $50,6244$. 
23. (a) Tanis, S. P.; Nakanishi, K. J. Am. Chem. Soc. 1979, 7, 409. (b) Oliveto, E. P.; Gerold, C.; Hershberg, E. B. J. Am. Chem. Soc. 1954, 76, 6113. (c) Howard, W. L.; Lorette, N. B. J. Org. Chem. 1960, 25, 525.

24. (a) Stork, G.; Zhao, K. Tetrahedron Lett. 1989, 30, 287. (b) Liu, H.-J.; Wiszniewski, V. Tetrahedron Lett. 1988, 29, 5471. (c) Olah, G. A.; Narang, S. C.; Mehrotra, A. K. Synthesis 1982, 965.

25. (a) Gonzalez, A. G.; Jorge, Z D.; Dorta, H. L.; Rodriguez, F. L. Tetrahedron Lett. 1981, 22 , 335. (b) Ramesh, C.; Mahender, G.; Ravindranath, N.; Das, B. Tetrahedron 2003, 59, 1049.

(c) Banger, B. P.; Upalla, L. S.; Sagar, A. D.; Sadavarte, V. S. Tetrahedron Lett. 2001, 42, 1163.

26. (a) Greene, T. W. In Protective Groups in Organic Synthesis, John Wiley and Sons; New York, 1981, Chapter 7, pp. 232-233. (b) Siegel, M. G.; Hahn, P. J.; Dressman, B. A.; Fritz, J. E.; Grunwell, J. R.; Kaldor, S. W. Tetrahedron Lett. 1997, 38, 3357.

27. (a) Coppola, G. M. Synthesis 1984, 1021. (b) Ballini, R.; Petrini, M. Synthesis 1990, 336. (c) Ballini, R.; Petrini, M. J. Chem. Soc., Perkin Trans. 1 1988, 2563. (d) Das, B.; Banerjee, J.; Ramu, R.; Pal, R.; Ravindranath, N.; Ramesh, C. Tetrahedron Lett. 2003, 44, 5465. (e) Liu, Y.-S.; Zhao, C.; Bergbreiter, D. E.; Romo, D. J. Org. Chem. 1998, 63, 3471.

28. (a) Firouzabadi, H.; Iranpoor, N.; Khoshnood, A. J. Mol. Catal. A: Chem. 2007, 274, 109. (b) Sreedhar, B.; Radhika, P.; Neelima, B.; Hebalkar, N. J. Mol. Catal. A: Chem. 2007, 272, 159. (c) Das, B.; Reddy, V. S.; Krishnaiah, M.; Rao, Y. K. J. Mol. Catal. A: Chem. 2007, $270,89$. (d) Kumar, S. R.; Leelavathi, P. J. Mol. Catal. A: Chem. 2007, 266, 65.

29. (a) Vijender, M.; Kishore, P.; Narender, P.; Satyanarayana, B. J. Mol. Catal. A: Chem. 2007, 266, 290. (b) Liu, Y.-H.; Liu, Q.-S.; Zhang, Z.-H. J. Mol. Catal. A: Chem. 2008, 296, 42. (c) Solladie-Cavallo, A.; Lupattelli, P.; Bonini, G. J. Org. Chem. 2005, 70, 1605.

30. (a) Nasser, I.; Ford, K. Tetrahedron Lett. 1998, 54, 9475. (b) Das, B. C.; Marrippan, G.; Saha, S.; Bhowmik, D.; Chiranjib J. Chem. Pharm. Res. 2010, 2, 113. (c) Wang, S.-Y.; Ji. S.J.; Loh, T.-P. Synlett 2003, 2377.

31. (a) Pal, R.; Mandal, T. K.; Mallik, A. K. J. Indian Chem. Soc. 2009, 86, 402. (b) Pal, R.; Mandal, T. K.; Mallik, A. K. J. Indian Chem. Soc. 2010, 87, 711.

32. Shiri, M.; Zolfigol, M. A.; Kruger, H. G.; Tanbakouchian, Z. Chem. Rev. 2010, 110, 2250.

33. (a) Pal, R.; Mandal, T. K.; Guha, C.; Mallik, A. K. J. Indian Chem. Soc. 2011, 88, 711. (b) Mandal, T. K.; Pal, R.; Mondal, R.; Mallik, A. K. E-J. Chem. 2011, 8, 863.

34. (a) Ramesh, C.; Banerjee, J.; Pal, R.; Das, B. Adv. Synth. Catal. 2003, 345, 557. (b) Ke, B.; Qin, Y.; Wang, Y.; Wang, F. Synth. Commun. 2005, 35, 1209. (c) Farhanullah; Sharon, A.; Maulik, P. R.; Ram, V. J. Tetrahedron Lett. 2004, 45, 5099.

35. (a) Lu. J.; Bai, Y. Synthesis 2002, 466. (b) De, S. K.; Gibbs, R. A. Synthesis 2005, 1748. (c) Sarada, T.; Kobayashi, F. Sakai, N.; Konakahara, T. Org. Lett. 2009, 11, 2161.

36. (a) Das, B.; Reddy, K. R. Helv. Chem. Acta 2006, 89, 3109. (b) Das, B.; Banerjee, J. Chem. Lett. 2004, 33, 960. 
37. (a) Roma, G.; Braccio, M. D.; Grossi, G.; Mattioli, F.; Ghia, H. Eur. J. Med. Chem. 2000, 35, 1021. (b) Chen, Y.-L.; Fang, K.-C.; Sheu, J.-Y.; Hsu, S.-L.; Tzeng, C.-C. J. Med. Chem. 2000, 44, 2374.

38. (a) Fuens, R.; Erdelen, C. Ger. Offen 1995, 4, 336307. (b) Krishna, R.; Pande, B. R.; Bharthwal, S. P.; Parmer, S. S. Eur. J. Med. Chem. 1980, 15, 567. (c) Das, N. B.; Mittra, A. S. Indian J. Chem. 1978, 16B, 138.

39. (a) Katritzky, A.; Li, Q.-L.; Fan, W.-Q. J. Heterocycl. Chem. 1988, 25, 1287. (b) Hooper, M.; Pitkethly, W. J. Chem. Soc., Perkin Trans. 1 1972, 1607.

40. Belmont, P.; Bosson, J.; Godet, T.; Tiano, M. Anticancer Agents Med. Chem. 2007, 7, 139.

41. (a) Sessler, J. L.; Camiolo, S.; Gale, P. A. Coord. Chem. Rev. 2003, 240, 17. (b) Gale, P. A.; Sessler, J. L.; Kral, V.; Lynch, V. J. Am. Chem. Soc. 1996, 118, 5140. (c) Allen, W. E.; Gale, P. A.; Brown, C. T.; Lynch, V. M.; Sessler, J. L. J. Am. Chem. Soc. 1996, 118, 12471. (d) Bachmann, J.; Nocera, D. G. J. Am. Chem. Soc. 2005, 127, 4730.

42. (a) Das, B.; Damoder, K.; Chowdhury, N.; Kumar, R. A. J. Mol. Catal. A: Chem. 2007, 274, 148. (b) Hou, R.-S.; Wu, J.-L.; Cheng, H.-T.; Xie, Y.-T.; Chen, L.-C. J. Chin. Chem. Soc. 2008, 55, 915. (c) Abonia, R.; Cuervo, P.; Insuasty, B.; Quiroga, J.; Nogueras, M.; Cobo, J.; Meier, H.; Lotero, E. Open Org. Chem. J. 2008, 2, 26.

43. Holla, B. S.; Mahalinga, M. M.; Poojary, B.; Asok, M.; Akberali, P. M. Indian J. Chem. 2006, $45 B, 568$.

44. Abonia, R.; Cuervo, P.; Castillo, J.; Insuasty, B.; Quiroga, J.; Nogueras, M.; Cobo, J.; Meier, H.; Lotero, E. Tetrahedron Lett. 2008, 49, 5028.

45. Das, B.; Thirupathi, P.; Mahender, I.; Reddy, V. S.; Rao, Y. K. J. Mol. Catal. A: Chem. 2006, 247, 233.

46. Chauhan, S. M. S.; Garg, B.; Bisht, T. Molecules 2007, 12, 2458.

47. (a) Lambert, R. W.; Martin, J. A.; Merrett, J. H.; Parkes, K. E. B.; Thomas, G. J. Chem. Abstr. 1997, 126, p212377y, PCT Int. Appl. WO 9706178, 1997. (b) Hideo, T. Chem. Abstr. 1981, 95, 80922b, Jpn. Tokkyo Koho JP 56005480, 1981.

48. (a) Sun, W.-C.; Gee, K. R.; Haugland, R. P. Bioorg. Med. Chem. Lett. 1998, 8, 3107. (b) Oyamada, J.; Jia, C.; Fujiwara, Y.; Kitamura, T. Chem. Lett. 2002, 380.

49. (a) Currens, M. J.; Mariner, J. M.; Mcmahon, J. B.; Boyd, M. R.; J. Pharmacol. Exp. Ther. 1996, 279, 652. (b) Currens, M. J.; Gulakowski, R. J.; Mariner, J. M.; Moran, R. A.; Buckheit, R. W. Jr.; Gustafson. K. R.; McMohan, J. B.; Boyd. M. R. J. Pharmacol. Exp. Ther. 1996, 279, 645.

50. (a) Mortensen, D. J.; Rodriguez, A. L.; Carlson, K. E.; Sun, J. H.; Katzenellenbogen, B. S.; Katzenellenbogen, J. A. J. Med. Chem. 2001, 44, 3838. (b) Francesconi, I.; Wilson, W. D.; Tanious, F. A.; Hall, J. E.; Bender, B. C.; Tidwell, R. R.; McCurdy, D.; Boykin, D. W. J. Med. Chem. 1999, 42, 2260.

51. Ko, S.; Yao, C.-F. Tetrahedron Lett. 2006, 47, 8827.

52. Sabou, R.; Hoelderich, W. F.; Ramprasad, D.; Weinand, R. J. Catal. 2005, 232, 34.

53. Gunnewegh, E. A.; Hoefnagel, A. J.; Bekkum, H. V. J. Mol. Catal. 1995, 100, 87. 
54. Kalena, G. P.; Jain, S.; Banerjee, A. Molecules 1997, 2, 100.

55. Talinli, N.; Akar, A.; Aydogan, A. C. Tetrahedron 1987, 43, 3505.

56. Young, J.-J.; Jung, L.-J.; Cheng, K.-M. Tetrahedron Lett. 2000, 41, 3415.

57. Palmieri, A.; Gabrielli, S.; Ballini, R. Chem. Commun. 2010, 46, 6165.

58. Schinzer, D.; Kabbara, J.; Ringe K. Tetrahedron Lett. 1992, 33, 8017.

59. (a) Hanaya, T.; Sugiyama, K.; Kawamato, H.; Yamamoto, H. Carbohydr. Res. 2003, 338, 1641. (b) Kralikova, A.; Budesinky, M.; Masojidkova, M.; Rosenberg, I. Tetrahedron 2006, 62, 4917. (c) El Kam, L.; Gaultier, L.; Grimoud, L.; Dos Santos, A. Synlett 2005, 2335. (d) Dolle, R. E.; Herpin, T. F.; Shimshock, Y. C. Tetrahedron Lett. 2001, 42, 1855.

60. (a) Lee, M. V.; Fong, E. M.; Singer, F. R.; Guenett, R. S. Cancer Res. 2001, 61, 2602. (b) Kafarski, P.; Lejczak, B. J. Mol. Catal. B: Enzym. 2004, 29, 99.

61. (a) Alonso, E.; Alonso, E.; Solis, A.; del Pozo, C. Synlett 2000, 698. (b) Meyer, J. H.; Barlett, P. A. J. Am. Chem. Soc. 1998, 120, 4600. (c) Allen, M. L.; Fuhrer, W.; Tuck, B.; Wade, R.; Wood, J. M. J. Med. Chem. 1989, 32, 1652.

62. Maryanoff, B. E.; Reitz, A. B. Chem. Rev. 1989, 89, 863.

63. Tajbakhah, M.; Heydari, A.; Khalilzadeh, M. A.; Lakouraj, M. M.; Zamenian, B. Synlett 2007, 2347.

64. Sudhakar, D.; Siddaiah, V.; Rao, C. V. Synth. Commun. 2011, 41, 976.

65. Kunda, U. M. R.; Mudumala, V. N. R.; Gangireddy, C. S. R.; Nemallapudi, B. R.; Sandip, K. N.; Cirandur, S. R. Chin. Chem. Lett. 2011, 22, 895.

66. (a) Michael, J. P.; Koning, C. B.; Hosken, G. D. Tetrahedron 2011, 57, 9635. (b) Dannhardt, G.; Bauer, U.; Nowe, J. J. Prakt. Chem. 1998, 340, 256. (c) Wang, Y.-F.; Izawa, T.; Kobayashi, S.; Ohna, M. J. Am. Chem. Soc. 1982, 104, 6465. (d) Natalie, D. E.; Donna, S. C.; Khurana, M.; Noha, N. S.; James, P. S.; Sylvia, J. H.; Abraham, N.; Robert, S. T.; Jacqueline, A. M. Eur. J. Med. Chem. 2003, 38, 49.

67. Narsaiah, A. V.; Reddy, A. R.; Reddy, B. V. S.; Yadav, J. S. Open Catal. J. 2011, 4, 43. 


\section{Authors' biographical data}

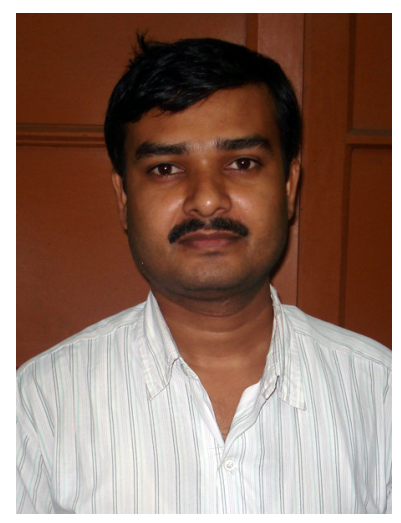

Rammohan Pal was born in 1978 in Kolkata, India. He obtained his B.Sc. in 1999 and M.Sc. in 2001 in Chemistry from University of Calcutta, India. He worked as a DBT-project fellow at the Biological Department of Chemistry, Indian Association for the Cultivation of Sciences (IACS), Kolkata and as a UGC-JRF at the Natural Product Laboratory, Indian Institute of Chemical Technology (IICT), Hyderebad, India. He carried out his predoctoral research work at the Department of Chemistry, Jadavpur University under the supervision of Prof. Asok Kumar Mallik. He received his Ph.D. degree in 2011 from Jadavpur University on synthesis and reactions of some nitrogen heterocycles. He has published over 13 scientific papers. His current research interests cover the development of synthetic methodology, green chemistry and synthesis of heterocyclic compounds. Presently, he is an Assistant Professor of Organic Chemistry at the Acharya Jagadish Chandra Bose College, Kolkata, India.

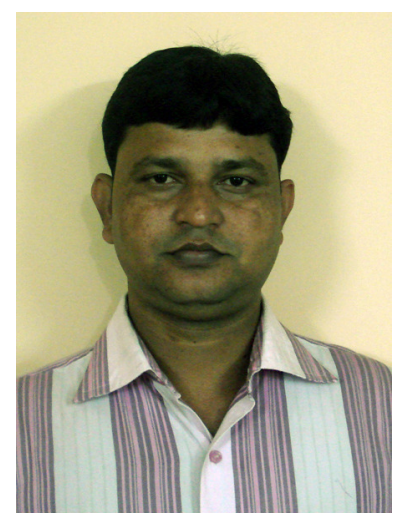

Taradas Sarkar received his B.Sc. and M.Sc. in Chemistry from the Burdwan University, India. He carried out his predoctoral research work at Bose Institute, Kolkata on the biophysical study of structure-function relationships of tubulin, a microtubular protein and received his $\mathrm{Ph}$.D. in 2004 from Jadavpur University, Kolkata. His postdoctoral work at NCI-Frederick, NIH, Maryland (2006-2008) was primarily on biophysical and cell biological studies for preliminary screening of antimitotic drugs. He has published over 15 scientific papers in leading international 
journals. Presently, he is an Assistant Professor of Physical Chemistry at the Acharya Jagadish Chandra Bose College, Kolkata, India.

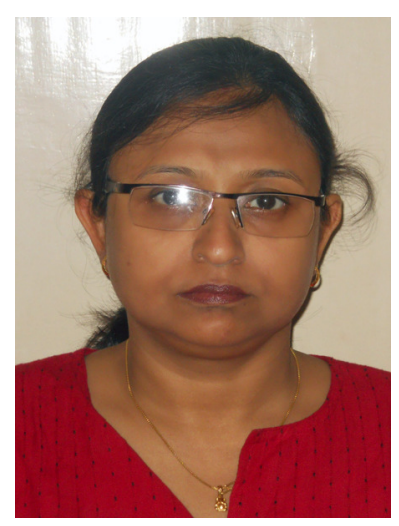

Shampa Khasnobis completed her B.Sc. in 1991 and M.Sc. in 1993 from University of Calcutta, India. Her predoctoral research work at the Department of Chemistry, Bose Institute, Kolkata was primarily based on synthesis and reactions of nitrogen and oxygen heterocycles. She received her Ph.D. degree from Jadavpur University in 2001. Her postdoctoral work at the Department of Microbiology, Colorado State University, Fort Collins, USA was mainly on synthesis and biological assay of bacterial polysachharides as a part of antituberculosis drug research. She has published over 12 scientific papers in journals of international repute. Presently, she is working as an Assistant Professor of Organic Chemistry at the Acharya Jagadish Chandra Bose College, Kolkata, India. 